\title{
Does Opening Complaints Data Change Company and Consumer Behavior? Evidence from the Consumer Financial Protection Bureau*
}

\author{
Kweku A. Opoku-Agyemang ${ }^{\dagger}$
}

\begin{abstract}
I analyze a technological change which improved the public monitoring of financial customer treatment. This major assessment of the Consumer Financial Protection Bureau is based on its exposing credit card-related complaints online while keeping mortgage-related complaints concealed. Exposed companies were more likely to close complaint files while providing explanations and relief to aggrieved consumers and in a timely manner. The transparency policy seems uncompromised by economic inequality. Consumers procrastinate in reporting exposed banks while rewarding exposed banks for their improved behavior with new accounts. Debt remained generally stable. Surprisingly, both consumers and banks benefit when offending banks are exposed online.
\end{abstract}

Keywords: financial reform, open data, transparency, credit card, mortgage, Consumer Financial Protection Bureau.

JEL Codes: D18, G20, G28, H40.

${ }^{*}$ I thank Isha Ray and several participants at my ERG invited lecture and colloquium at UC Berkeley for providing helpful feedback. I also thank Ted Miguel, Temina Madon, and many others for encouragement. The findings are strictly and exclusively the perspectives of the author, and do not represent the views of any other individual, institution or organization. The usual disclaimer applies.

${ }^{\dagger}$ University of California, Berkeley, Center for Effective Global Action and Cornell Tech. Email: kweku@berkeley.edu. 


\section{Introduction}

The Wells Fargo scandal of 2016 exposed financial company malpractices such as fraudulent account creation, leading to much public outrage (see Miller 2016 for a report). Unfortunately, political lobbying by financial firms has been one reason why protecting consumers in the United States from such financial harm has proved challenging ${ }^{1}$. It remains unclear how to minimize misbehavior and relevant complaints that may arise when lenders have more information and power than consumers.

This paper analyzes the role that an innovative but controversial technological change has played in sidestepping lobbying to improve credit card company behavior. On June 19, 2012, the Consumer Financial Protection Bureau (CFPB) launched a new database, spanning an expanding universe of credit card complaints it was receiving from across the United States. To boost accountability in the credit card sector, the CFPB followed up on each complaint with every implicated institution, and exposed all consumer complaints online. Mortgage complaints, another area of concern since the 2008 financial crisis, were excluded from this open data initiative and only similarly released in March of the next year. This policy is only one manifestation of a broader transparency drive that followed the 2008 crisis, dating back to an announcement by former President Barack Obama on his first full day in office in 2009 to foster openness-led governance ${ }^{2}$.

The paper asks: how did credit card stakeholders react to being exposed online, relative to unexposed mortage firms? Social scientists believe that transparency may benefit financial markets. However, political constraints are critical: when the open data initiative was proposed in January of 2012, trade groups sent policy makers strongly-worded letters warning that the potential leakage of trade secrets would unfairly cast companies "in the shadow of possible guilt," according to the Consumer Data Industry Association (Bloomberg 2013). Figure 1 shows the growth in the total number of companies implicated in consumer complaints.

[Figure 1 Goes Here]

\footnotetext{
${ }^{1}$ The Office of the Comptroller of the Currency, which was originally responsible for handling financial complaints, had only been able to pursue one single financial complaint case by 2004 (PBS 2004; New York Times 2010). For discussions on lobbying as political barriers to reforming the industry, see Mann (2005) and New York Times (2000).

${ }^{2}$ See Huijboom, and Van den Broek (2011) for an overview of how other countries are attempting similar initiatives.
} 
To contribute to this discussion, this paper studies the CFPB's open data initiative as a change in technology that increases the monitoring of credit card firms with respect to how they treat their customers. I find the CFPB's open data initiative on credit card complaints to significantly motivate banks to self-reform their consumer relationship dynamics. Companies are significantly more likely to respond to consumer complaints in a positive way after being exposed online, and such companies appear to be modifying their behavior to protect their profit-maximizing goals be safeguarding their reputations. I also find surprising evidence that reported credit card infractions are consistently logged later in the month after the open data policy was launched, which I explain as exposed banks becoming slightly more time-inconsistent in terms of offending their consumers. I also link the better overall customer service to a newfound boldness among consumers, who are more likely to dispute exposed companies. I discuss the results in three phases.

The first part of the paper focuses on various bank responses to individual consumer complaints and how these have changed following the open data policy. The associational findings suggest that banks are more likely to close a complaint file or answer the relevant concern to a consumer's satisfaction; more likely to address credit complaint files with explanations as to why the complaint may have occurred or the infraction justified; more likely to provide some level of monitory relief and more likely to provide a degree of non-monitory relief. Companies have literally no idea how many of the internet-enabled US households ${ }^{3}$ actually observe their CFPB complaint open data online. By significantly and swiftly moving to resolve complaints positively, they appear to react in a worst-case scenario where everyone sees the data. I also analyze what the open data policy meant for how consumers engaged with companies. Although comapnies are more likely to respond positively following open data exposure, I find that consumer complaints are reported later every month, which may imply that consumers feel assured by the new status quo and procrastinate reporting. The positive company responses and later reporting may also mean that exposed firms become slower to cause such complaints.

The second part of the paper investigates whether the open data initiative was compromised by politics. Given that the geographic diversification of banks reduces bank valuations by worsening agency problems ( Goetz, Laeven and Levine 2013), we might expect exposed banks located in areas

\footnotetext{
${ }^{3}$ About $74 \%$ of US households are estimated to have internet access, in a report for the United States Census Bureau (File and Ryan 2014).
} 
of low social mobility to have more complaints (perhaps if customers in such areas are treated less satisfactorily for their relatively lower incomes, for example). Similarly, highly mobile areas might be anticipated to generally report fewer complaints by virtue of the preferential treatments some richer individuals might experience due to their relatively high financial worth and reference incomes. I explore potential connections between consumer complaints and themes of social mobility and economic inequality in the areas that host the banks.

I find no such statistically significant relationships in the data. I do not document any statistically significant relationships between being exposed to the open data (interacted with being in the top $4 \%$ counties, or even the bottom counties in the social mobility distribution). I also find no statistical relationship for consumers living in the wealthiest zipcodes (i.e. in areas such as Salt Lake City, Utah or San Jose, California), or even the least socially-mobile counties of Charlotte, North Carolina or Atlanta, Georgia). Thus, I do not generally find that economic inequality is, or is not particularly important, at least from an econometric standpoint; a surprising outcome in of itself. However, I do find that sending a complaint to a bank in the first week of the month is likely to have that complaint closed or dealt with success, relative to later in the month. Consumers are more likely to report dissatisfaction with their banks' reactions to their complaints when the data is open, which might be a sign that consumers feel emboldened by the open data initiative.

The open data policy may be expected to have had broader effects on credit card consumers and companies in the longer term. I find that the total number of credit card accounts grows significantly following the open data initiative. The credit card accounts increased by about 70 million accounts over the ensuing three years, representing a rise of $18 \%$. This result implies that consumer confidence in credit card industry was boosted by the open data policy and banks' increased accountability in response. Given that the CFPB's open data program was in session at the same time these additional accounts were being opened, it seems safe to assume that these new accounts better reflect consumer demand under transparency. I also show evidence suggesting the credit card debt was relatively stable during the period and only slightly changed, which may suggest that consumers were increasingly discretionary following the open data policy. This outcome is consistent with the hesitation of companies to cause infractions for consumers and slower reporting of complaints following the open data policy. 
The results have implications for both the behavioral and information economics literatures. First, open data acts in part as a commitment device, helping credit card companies treat customers better. At the same time, the effect of the open data policy on later complaints each month imply that the exposed companies also appear to showing less self-control in their abilities to cause consumer infractions to an extent. Such companies are more time-inconsistent as far as causing new complaints are concerned. It is possible that exposed companies may be putting more weight on inconveniencing consumers in the present, relative to the future. The result improves unusual information asymmetries (where banks know more than their clients about what happens within a bank to influence consumer complaints) with a novel transparency policy. Consumers seem to respond by opening more accounts for exposed companies, which may mean an approval of the improved information gained by consumers. In so doing, another usual intuition the paper complicates is that public intervention (considered in this case as harnessing the wisdom of the crowd) into the financial affairs of Wall Street is necessarily market-distorting and not market-correcting.

\section{The CFPB}

In this section, I briefly profile the Consumer Financial Protection Bureau and its key characteristics. The Bureau was instituted as the centerpiece of the Dodd-Frank Wall Street Reform and Consumer Protection Act, passed in 2010 as a legislative response to the financial crisis. Many financial firms vigorously opposed the establishment of the unusual institution, and various policy makers blatantly attempted to limit the policy reach of the CFPB and even its funding (Wall Street Journal 2011). Consumers generally had little avenues to defend themselves when faced with irregularities such as financial harassment from credit card or mortgage or other companies. The social stigma associated debt and poverty may have held some Americans from pushing back when faced with company behaviors that objectively warranted complaints. The CFPB was set up to promote accountability in consumer finance ${ }^{4}$.

The CFPB public database was launched on July 19, 2012 with the intention of using social

\footnotetext{
${ }^{4}$ The need for and background of the Consumer Financial Protection Bureau are traced across various works (see Bertrand and Morse 2011; Campbell, Jackson, Madrian, and Tufano (2010, 2011), Johnson 2012; Slattery 2013; Hastings, Mardian and Skimmyhorn 2013; Campbell 2016). I instead focus on the CFPB's open data policy.
} 
pressure to improve customer service in this regard. The program began with credit card consumer complaints originally, and were expanded into including mortgages and other kinds of complaints on March 28, 2013. Consumers' permissions are secured during complaint reporting for anonymously sharing complaints. During the program, complaints were collected across email, phone, fax, postal mail referral, or web channels (as preferred by complaing consumer).

On receipt by the CFPB, all consumer complaints are forwarded to the financial institution in question to bring the consumer complaint to the attention of the credit market organization, and each organization is given 15 days to respond after the date the complaint is forwarded to the company. After 15 days, or after the organization responds (whichever comes first), the complaint in question is anonymously uploaded to the CFPB website, which is updated on a daily or almost daily basis with new complaints. The CFPB presents reports to Congress on a bi-annual basis and also cooperates with state and federal agencies.

I use the information from the CFPB database to contextualize credit card and mortgage complaints. First, I use the specific issue identified in the complaint, which is entered in plain text. The issues raised by consumers span various topics, ranging from the "identity theft or fraud or embezzlement" and "unsolicited issuance of credit cards", "APR or interest rate", "advertising and marketing", "application processing delay", "arbitration", "balance transfer issue" "billing issues", "collection practices" "improper use of credit report", "billing statement" and other complaint topics (discussed in detail in the next section). At one layer below the reported issue are sub-issues, which are relatively specific explanations of the above-mentioned issues, ranging from "account status" to "problem cancelling or closing account" or "problem getting report or credit score" or "problem with fraud alerts."

The data allows us to pinpoint when each complaint was made to the CFPB, when the same complaint was forwarded to the bank, as well as the bank response and whether or not and how a consumer complaint file was closed. This rich information also allows us to gain information on whether a complaint was disputed by the bank in question, what the company response to the consumer was, and whether the response was considered satisfactory by the consumer. 


\section{Data}

I draw on information from the CFPB database on complaints from individual consumers and banking organizations. This section describes the data sources and key variable definitions ${ }^{5}$. The data is from November 2011 through June 2012 (when the credit card data was exposed to the public) until March 2013, (when mortgage data was also opened to the public). I provide descriptive statistics and discuss identification across the exposed credit card complaints, and unexposed mortgage complaints, which serve as the comparison group. I am mainly interested in the following queries: Date received: When did the CFPB receive the complaint? Product: What was the type of financial product did the consumer identify? Issue: What specific issue did the consumer identify in the complaint? Submitted via: How was the complaint submitted? Date sent to the company: When did the CFPB forward the complaint to the company? Company response to consumer: How did the company respond to the complaint? Consumer disputed: Did the consumer dispute the company's response?

\section{Empirical Approach}

My approach to estimating company and consumer responses to transparency is based on a relationship that open data must have with how companies deal with consumer complaints. I model company responses in the data as:

$$
y=f(\theta, \mathrm{T}, Q, \mathbb{X})
$$

whereby company responses or outcomes $y$ are a function of $\theta$ (whether the data is transparent, exposed or open to the public or not), $\mathrm{T}$ (the type of complaint or whether identified as being from the credit card or mortgage industry), $Q$, (how the complaint was submitted), and $\mathbb{X}$, the specific issue which motivated the reporting of the complaint.

Rather than observing sheer or true transparency $\theta$ where I can independently confirm that all individuals and companies are perfectly aware of the CFPB open data initiative, my approach focuses on using open data as a tool that allows the public to gain power over anti-social companies-while

\footnotetext{
${ }^{5}$ See CFPB (2016) for details.
} 
requiring that companies imagine that all individuals are aware of online complaints ${ }^{6}$. The desire to protect company reputations and maximize profits may mean that company agents may prefer to self-corect their behavior without knowing the degree to which they are observed. This approach means that I do assume that companies are all aware of the transparency policy, which is plausible given the resistance to the policy noted earlier in the text. Based on this assumption, I use the universe of credit card versus mortgage consumer complaints within the studied time-frame to study whether opening credit complaints to the public in near-real-time changed how companies and consumers interact. I first document statistically significant associations and use a natural-experimental behavioral setting to unpack the correlations I document.

Of course, simply finding that complaints that were exposed to the public were followed by responses that were more sympathetic to consumers may imply that companies improved service quality for reasons that are unrelated to the open data initiative. I minimize this concern by comprehensively considering how the open data initiative affected the timing of the same reported complaints, an issue which I ultimately estimate to be exogenous via parallel trends regressions. Another reason why the relationship between the open data policy and the timing of complaints may be important has to do with the behavioral implications: the open data policy may make companies less time-inconsistent with respect to their causing consumer complaints. The intuitive identifying assumption of the comprehensive effects of open data is that if the timing of complaints changes significantly following the open data policy, which is exogenous to the time horizon, then this timing has behavioral implications that would help contextualize any significant associations I may see between the open data policy and how companies respond to these same complaints. On the other hand, if the timing of complaints does not significantly change following the exogenous open data reform, then any associations between open data and company responses may have a relatively subdued policy relevance.

I am especially interested in the estimated effects of credit card open data exposure to understand two related main hypotheses: the effect of transparency on accountability and on company behaviour.

\footnotetext{
${ }^{6}$ This assumption is weaker than the presumption that everyone in the United States is aware of the initiative, but appropriate for the context.
} 
- Hypothesis: Exposed credit card companies are more likely to

1. Successfully resolve complaints and close complaint files

2. Close files while providing an explanation to clients

3. Provide monetary relief to satisfy aggrieved customers

4. Provide non-monetary relief to satisfy aggrieved customers

5. Close complaints in a timely manner

All of the give sub-hypotheses are motivated by the need for companies to maximize their profits by protecting their reputations. We also think of companies as being time-inconsistent, so that being exposed affects the timing of future complaints. Specifically, the second hypothesis conjectures that exposed companies would be affected in terms of how time-inconsistent they are in provoking complaints. A company may be tempted to cause a complaint, but being exposed online would cause a delay in when the event leading to a complaint occurs, and hence, when the complaint is made.

- Hypothesis: Exposed credit card companies receive complaints later every month relative to unexposed companies.

Two stories of heterogeneity may be important for the data, however. First, I might lack information on some issues that represent different topics in qualitatively subjective ways. I was admittedly not privy to the actual experience that triggered a complaint, but I address this by including 37 issue dummies that provide all of the 37 themes of the issues at play in the complaint texts. I also include time dummies.

How complaints are submitted may be also important to both banks and the CFPB. I summarize complaint-specific submission characteristics (i.e. by phone, fax, email, postal mail, referral, web). Due to standard behavioral reasons, complaints that are made over the phone, where a CFPB representative must provide some reaction in near-real-time might be anticipated to proceed with a different level of urgency relative to complaints submitted via postal mail. Similarly, complaints delivered over the web may reflect a level of tech-savviness that may mirror complaints sent by 
email, but be qualitatively different and cover a different demographic from complaints sent by fax machine. Consumers may also be influenced by the CFPB initiative, in the following sense:

- Hypothesis: Exposed credit card companies receive more new accounts from consumers relative to unexposed companies, with debt levels in exposed firms remaining stable.

. I hypothesize that consumers reward companies for positively responding to the transparency initiative by opening more accounts in such organizations. At the same time, if the open data initiative has the effect of making consumers more aware of the potential complications of banking that can lead to consumer complaints, consumers may be relatively hesitant to accumulate debt in exposed companies relative to unexposed companies during the study period.

The database is comprehensive representing all of the United States, as well as military "states" (AA - Armed Forces Americas (except Canada), AE- Armed Forces Africa, AE - Armed Forces Canada, AE - Armed Forces Europe, AE - Armed Forces Middle East and AP - Armed Forces Pacific), which may be important as such military states may be particularly prone to credit card harassment over non-existent debts according to some media reports ${ }^{7}$. I also control for companies that received more complaints than the average (157.3 complaints).

\subsection{Descriptive Statistics}

In this section, I present the summary statistics for all of the variables drawing on both credit card and mortgage industries.

The summary statistics are shown as the averages for each variable in Table 1. The sample size is 74,244 . I first report the descriptive statistics of the thirty-eight issues consumers raise based on their experiences, and which appear to have motivated their contacting the CFPB to lodge a complaint. About $28 \%$ of consumers complained about APR or interest rate issues on average,

\footnotetext{
${ }^{7}$ According to Pyke (2014) for example, military personnel are particularly vulnerable to financial harassment according to the Consumer Financial Protection Bureau's (CFPB) Office of Servicemember Affairs (OSA); thus I control for military state effects.
} 
whereas only $1 \%$ complained about advertising and marketing issues on average. An issue which received only around $0.1 \%$ of complaints on average (about 742 ) related to application processing delays for consumers.

[Table 1 Goes Here]

Issues related to application originators or mortgage brokers were raised by $5 \%$ of consumers. Arbitration and balance transfer issues each covered less than $1 \%$ of complaints on average. Billing dispute issues were raised by around $4 \%$ of the consumers on average, with billing statement issues being raised by less than $1 \%$ of consumers. Other issues raised by complainants included credit line increases or decreases, credit card underwriting, customer service issues, identity theft/fraud/embezzlement, loan servicing, payments escrow accounts, settlement processes and costs, privacy issues, rewards, sale of account, transaction issue, unsolicited issue of credit card. I now describe how consumers submitted these complaints.

Perhaps unsurprisingly (for convenience reasons), the vast majority of reported complaints, were submitted by the web (at an average of $46 \%$ ), and referrals accounted for $38 \%$ on average. Around $7 \%$ of the complaints were submitted by phone. Submitted by postal mail accounted for around $6.5 \%$ on average of the complaints. Submitted by fax accounted for $1.6 \%$ the submitted complaints on average, and Submitted by email were the least-used submission method at $0.2 \%$. Figure 2 shows bar graphs for the frequency of complaints, broken down by submission method. The first bar graphs show the frequency of complaints submitted without the open data component and the second bars show the frequency of complaints submitted under the open data regime. Each set of bar graphs shows the frequency of complaints and how they have changed following the open data policy. From the credit card and mortgage complaints, there is a drop in total complaints following the open data initiative, from 13,610 complaints to 11, 352 complaints (a reduction of 2258 complaints, or about 9 percent).

[Figure 2 Goes Here] 
Returning to Table 1, I discuss the various independent variables and outcome variables. The open data will refer to credit card complaints received after June 19, 2012. I also classify credit card and mortgage complaints. Credit card complaints are around $27 \%$ of the data and mortgage complaints account for $73 \%$ of the sample. Companies tended to respond by closing a complaint file; closing a file with some explanation; contributing monetary relief or contributing non-monetary relief; or responding in an untimely timely manner to various extents. Company responses that were coded as "closed with relief" or "closed without relief" were not used in the analysis as one cannot ascertain whether such relief was monetary or non-monetary in scope. From Table 1, the complaints tended to be sent to the CFPB around the middle of the month, or on the 16th day, on average.

\section{Results}

\subsection{Financial Company Responses to Open Data}

I begin the results section by discussing the relationship between open data and credit complaint responses by companies. I use Ordinary Least Squares regressions to study the associations with robust standard errors involving clustering at the state identifier. Table 2 reports the relationship between complaints submitted concerning credit cards during the open data policy implementation and the likelihood that a complaint was successfully closed. The final regression includes all independent variables in each table. I find that the open data was followed by a $1 \%$ increase in the likelihood of closing a complaint file. Interestingly, credit cards had a negative association with the likelihood of complaint files being closed when the open data platform was absent, implying that the policy had the implication of changing the sign of the relationship between opening complaints and company responses. None of the submission mechanisms (email, phone, postal mail, referral, or web) seem to have mattered, and the results are identical when I account for all thirty-seven complaint issues.

[Table 2 Goes Here]

Table 3 investigates the relationship between the open data policy initiative and closing consumer complaints with explanation. I find a stronger association of the open data policy with the response 
of closing a file with some kind of explanation estimated at around $46 \%$ (which is large relative to estimate from simply closing the file, as seen in Table 2 above). Again, credit cards show a negative relationship with the positive response of companies responding with explanation when the open data policy was not in play, implying a turnaround that is more perceptive than that seen in Table 2 . I find that submissions by referrals and the web have negative relationships with the likelihood of a complaint being closed with some explanation.

[Table 3 Goes Here]

Table 4 reports how the open data relates to companies closing files with some kind of monetary relief. Interestingly, credit cards are associated with the likelihood of gaining such relief only to a minor extent prior to the open data policy, however once the policy is in place, I find a strong (above $20 \%$ ) increase in the likelihood of companies responding to complaints by providing some monetary relief. The submission and other factors do not appear to play a statistically significant role.

[Table 4 Goes Here]

In Table 5, I look at the the same regression but with complaints closed with non-monetary relief as the dependent variable. Interestingly, the estimates are broadly similar to the finding of a stronger likelihood of providing monetary relief. This result might mean that the companies think of monetary relief and non-monetary relief as near-substitutes to some minor extent in the open data policy environment.

\section{[Table 5 Goes Here]}

I find that companies are significantly less likely to respond to complaints in an untimely manner following the open data policy. I show this result in Table 6. Again, I see a reversal of the relationship of credit card complaints and the likelihood of companies to respond in a negative manner. I also note 
that the submission mechanisms used yield significant relationships with how quickly companies respond, with the exception of the postal mail, which may simply relate to the fact that it is the slowest submission approach possible.

[Table 6 Goes Here]

\subsection{Financal Company Responses, Open Data and Time Inconsistency: A Natural Experiment}

In this sub-section, I explore whether the open data policy affected how quickly complaints were caused and reported. The goal is to understand whether the open data policy had any effect on how hesitant companies become to cause complaints in the future. Given the plausible exogeneity of open data on when any complaint is actually caused and reported, I look at how companies respond to the open data policy with respect to the timing of when a complaint was filed with the CFPB. I think of each month as a potential "reset" of company-consumer interactions, given that most people would receive pay at the start of the month.

The dependent variable is the day of the month. Table 7 provides evidence of parallel trends, looking at the effect of credit card complaints on the timing of complaint reporting prior to the open data policy. Neither the credit card type variable nor the thirty-seven complaint issue dummies from Table 1 that motivated complaints are found to have a statistically significant relationship to the timing of complaints, which I base on the day of the month. None of the complaint submission mechanisms significantly vary with the timing of complaints as well. The results look similar whether or not I control for time dummies for clarity's sake and the final column of Table 7 includes both time dummies and dummies for whether a company's complaints were above average. None of the independent variables of Table 7 have a statistically significant relationship with the dependent variable, the day of the month a complaint was received. These results imply that the effect of the open data policy on the timing of complaints is nearly random, unlike the correlational relationship with company behavior in the previous section. 
[Table 7 Goes Here]

In Table 8, I analyze the relationship between the open data policy and its impacts on how early or late in the month a complaint is received, which serves as a proxy for how nervous or hesitant companies are about offending consumers while the open data platform is in session. I find an increase in about 1.6 to 1.7 days in how much time it takes for complaints to be reported on average, which is attributable to the open data program. The first two regressions show a negative relationship between a complaint relating to credit cards and the day a complaint is received, but this washes out when more variables are accounted for (in the third and final regressions). The results thus far can be summarized as open data making companies more accountable and improving their customer service efficiency.

[Table 8 Goes Here]

\section{Open Data and Financial Customer Socioeconomic Environ- ments}

In this section, I explore the possibility that the open data policy was compromised by politics (see Anzia and Moe (2016) for a discussion on how politicans have previously used policy for political ends in the public sector). The geographic diversification of banks (e.g. Goetz, Laeven and Levine (2013)) may have similar empirical bearings on understanding consumer complaints and bank responses within the context of open data if customers' broader economic environments are important. For example, one might expect struggling countries to have relatively low levels of awareness of their rights, and this outcome may tempt financial companies which are based in the area to be relatively unaccountable. Wealthier counties that are relatively socially mobile may have relatively accountable branches of companies for similar reasons. I assess the open data result at levels of specific counties, coordinated by zipcodes in the data. To investigate the above possibilities, I focus on the extreme fringes of the social mobility distribution for three related reasons: perhaps being in a relatively socially upward environment may translate in open data having more resonance relative to 
a less socially mobile setting. On the other hand, open data may simply favor the already wealthy and show stronger relationships with improved company responses and nervousness to offend customers. The goal of the open data initiative was to democratize consumer finance, so social mobility may be an apropos laboratory to understand company accountability.

\subsection{Open Data and the Top 2 and Bottom 2 Counties in terms of Social Mo- bility}

In Table 9, I focus on the top 2 and bottom 2 socially mobile counties. The top two counties are Salt Lake City, Utah, and Pittsburgh, Pennsylvania. The bottom two are Atlanta, Georgia and Charlotte, North Carolina. These translate into the top $4 \%$ and bottom $4 \%$ counties in terms of social mobility, out of the 50th largest communiting zones (see Chetty, Hendren, Kline, and Saez (2014)).

I interact the open data exposure with complaints emerging from zipcodes that are located within the top 4 percent of the social mobility distribution (including areas such as Salt Lake City, Utah) as well as the lower 4 percent of socially mobile zipcodes (examples of which include Raleigh, North Carolina). I do not find any significant change in how companies respond (across the five metrics discussed in the previous section on how quickly and generously complaint files are closed), or the nervousness metric in terms of the timing in Table 9. The main results of companies being relatively responsive to complaints are robust to this specification. It is worth pointing out that perhaps the bounds selected are still relatively narrow, so I slightly expand the discussion in the next sub-section.

[Table 9 Goes Here]

\subsection{Open Data and the Top 3 and Bottom 3 Counties in terms of Social Mo- bility}

In Table 10, I investigate how the results look for zipcodes found in the top 6 percent and the bottom 6 percent with the understanding that perhaps this slightly broader range may contextualize the finding of no statistical importance of social mobility on consumer complaints, seen through 
the prism of the open data policy. These are the top 3 and bottom 3 counties in terms of social mobility. The top three consist of San Jose, California in addition to Salt Lake City, Utah and Pittsburgh, Pennsylvania, while the bottom 3 counties consist of Raleigh, North Carolina as well as Atlanta, Georgia and Charlotte, North Carolina. Again, although the main argument is robust to this broader specification, I cannot find any backing for the intuition that the extremely socially mobile or immobile have experienced statistically better or worse outcomes with respect to consumer complaint outcomes.

[Table 10 Goes Here]

\subsection{Company Responses to Open Data: Social Mobility in Charlotte, NC}

I now consider specific counties to look at the most focused geographical setting and come closer to understanding whether social mobility has any empirical bearing on complaint outcomes following the open data policy. I look at Charlotte, North Carolina, which had the lowest socially mobile zipcodes in terms of intergenerational progress. My hypothesis is whether people living in Charlotte while lodging complaints with the CFPB were especially or less likely to experience consumer finance issues following the open data policy. From Table 11, I do not find any significant change in complaint outcomes as a result of living in Charlotte, NC.

[Table 11 Goes Here]

\subsection{Company Responses to Open Data: Social Mobility in San Jose}

I next investigate whether the open data policy has had any bearing on complaint outcomes in San Jose, one of the most socially-mobile counties in the United States in terms of intergenerational advancement. I find no evidence to support the hypothesis that complaint outcomes are relatively different in spite of this social progress context. The Online Appendix reports results for other areas 
in the very top (Salt Lake City, UT, and Pittsburgh, PA) and very bottom parts of the social mobility distribution (Raleigh, NC and Atlanta, GA) finding the same general result.

\subsection{Consumer Engagement and Supplementary Results}

In the Appendix, I also look at consumer engagement connected to the open data initiative. Consumers appear to be $1.7 \%$ more likely to report dissatisfaction with a company response following the open data policy. This result implies that while the open data connotes nervousnes among bank companies, open data translates into consumer boldness. It is possible that consumers feel slightly more empowered to register their dissatisfaction due to the new transparent environment.

In the Online Appendix (Tables A5 through A9) I study whether the actual timing of the routing of consumer complaints from the CFPB may provide further details on bank responses to open data. Splitting these dates into weekly bins, I document an interesting hierarchy between when a complaint was received and how the complaint was resolved: complaints received on the first week generally had favorable responses, unlike later complaints. The first week is associated with a positive likelihood of files being closed, and files being closed with explanation having a negative association. The other third and fourth weeks generally have no relationship or a slightly negative association. It is possible from the first week response result that the timing motivates companies to move quicker.

\subsection{Effects of the Open Data Policy on Consumer Accounts}

It is possible that the open data policy may have had spillover effects into the number of accounts created. This is important as the number of accounts is an important metric to banking organizations and a potential indicator of the success of the CFPB in their estimation. If the CFPB's open data policy led to a significant drop in accounts for example, banks may be understandably less likely to support such an initiative. This section uses data from the Federal Reserve Bank of New York (2017) to see whether the open data program had any implications on the number of accounts opened throughout the credit card industry relative to the mortgage industry. From Figure 3, consumer 
accounts stabilize for mortgages from 2010 through 2016, although I observe a slight increase in the number of credit card accounts that coincides with the open data initiative. The credit card accounts increase from 383.36 million accounts in the second quarter of 2012 (when the credit card complaints were exposed) to 453.07 million accounts by the end of 2016, representing a total gain of 69.71 more credit accounts or a rise of $18 \%$. However, the effect seems to have been gradual, with a total of 388.87 million credit card accounts being in existence by the second quarter of 2013 (showing a short-term increase of $0.1 \%$ or 5.51 million more credit card accounts over the first year). Overall, it appears that exposed banks seem to be rewarded by consumers with slightly more accounts over time. Unexposed companies' accounts remain flat during the period. This outcome implies that the transparency initiative may have restored trust between companies and their customers to some extent, seen in the longer-term growth in accounts.

[Figure 3 Goes Here]

\subsection{The Open Data Policy and Total Credit Card and Mortgage Debt}

The open data policy may also have had spillover effects into the total amount of debt. The awareness of consumer complaints may have made consumers hesitant to take on further debt. In Figure 4, I notice that credit card debt remained nearly parallel to mortgage debt within the timeframe of 2010 through 2016. The credit card debt was about 0.6 trillion by the time the program was launched and 0.7 trillion about a year later. Although the open data encouraged banks to treat consumers better, this improved customer service may have also encouraged consumers to maintain or slightly increase their existing borrowing behavior. Debt levels remained generally high in the mortgage industry, although Figure 4 shows that mortgage debt was trending downwards from almost 8.9 trillion in the first quarter of 2010 to a low of about 8.1 trillion by the time the open data initiative was launched. By 2016 however, mortgage debts had returned to high levels of around 8.5 trillion. Both credit card and mortgage total debts appear to be relatively stable and were only influenced to a minor effect by the open data policy. Overall, exposed companies appear not to have been harmed by the transparency initiative. Borrowing trends remain relatively stable and were not negatively affected 
by being exposed by the CFPB. The slight growth in the number of accounts, however, implies that there may be benefits, (perhaps in a public relations sense) from improving customer service. Although the limitations of the data mean that I am unable to connect specific organizations to their debt levels or account numbers, the growth in account creation across the credit card industry imply that the results of the open data initiative are positive overall. This result contextualizes the earlier finding that exposed companies hesitate to cause infractions and that the consumers of exposed companies are slower to report such infringements.

[Figure 4 Goes Here]

\section{Policy Benefits and Limits of Using Open Data to Protect Con- sumers}

I contextualize the findings with implications that stem from the unusual policy environment in which the CFPB is embedded. I discuss how the CFPB yields several benefits over the status quo with respect to credit card complaints and harassment and comment on its limits.

First, the open data initiative is a policy mechanism for monitoring the credit card industry, according to the results. One can essentially think the open data initiative and the CFPB in terms of a special case of institutional design in the financial economy where focusing on the finer level of financial products (instead of the broader level of the financial lender) is relatively efficient at protecting consumers (Warren (2008) contains further motivation of the CFPB)).

Also, the open data initiative provides evidence for open data serving as a commitment devices (Ashraf, Karlan and Yin 2006; Bryan, Karlan and Nelson 2010), with the caveat that the transparency program was mandatory and not optional. By merely exploiting reputational aspects of profit maximization, the open data initiative appears to have exploited complaints to improve efficiency within the sector by lessening the qualitative severity of such infractions. However, how sustainable this unusual open data approach is in the long term remains an open question (Wilmarth Jr. 2012).

The open data initiative makes it possible to assess what appears to be the first case (to the best of 
my knowledge) where policy may reduce information asymmetries where lenders know more about debtors in financial interactions. Such information imbalances may be one reason for such rampant financial misbehavior. My findings present an unusual role reversal of the typical agency dilemma setting in financial markets, in that they consider the principal as the consumer and the agent as the bank company. Bank companies would generally have more detailed information on consumers than vice-versa, particularly on the internal factors within companies that may influence infringements and complaints. By exposing complaints to the public and routing complaints to companies for responses, this unique asymmetry is, overall, lessened. This approach supports existing analyses of information asymmetries which inherently exclude reconciling the incentives of antisocial principals with the needs of vulnerable agents.

Consumers may be reporting later if they feel less stigma in reporting to the CFPB and have significant confidence in the ability of the institution to protect such end users. Such comfort may partly account for the delayed reporting, although the associations between open data and company behavior may imply that the main channel is that companies also hesitate to cause complaints in the first place. These results come together to explain the growth in credit card accounts relative to mortgage accounts. The open data policy does not appear to have been discriminatory in its implementation: the specific location of a company branch and socioeconomic context, surprisingly, does not appear to be very important for the results. If one cannot tell whether a bank branch thinks its reputation will be affected by its wealthier or poorer consumers, one would be unable to prove whether or not open data makes banks respond more or less to the richest and poorest consumers. This conjecture partially explains the lack of statistical significance in the relationship between high and low social mobility interacted with open data and bank and consumner complaint behavior.

\section{Related Literature}

There is a growing multidisciplinary literature on open data policies (see Auer et al 2007; Reichman, Jones, and Schildhauer 2011; Huijboom, and Van den Broek 2011; Janssen, Charalabidis, and Zuiderwijk 2012; Zuiderwijk et al 2012). My approach focuses on quantifying the first economic reactions to open data in the US financial industry to the best of my knowledge, although my results 
are obviously in agreement with and building on this line of inquiry.

The credit card and mortgage markets are described in Agarwal, Chomsisengphet, Mahoney and Stroebel (2015) and Campbell, Giglio, and Pathak (2011) respectively. This is the very first paper to focus on how open data can, mostly in and of itself, create financial sector reform. One reason why the problem of financial complaints persist inspite of legislation may have to do with Schattschneider's famous adage that "policies make politics" (Anzia and Moe 2016). Although political constraints may hamper the effectiveness of financial policy, this appears to be less relevant with respect to this transparency initiative.

Reports and descriptive anecdotes in the media immediately following the policy noted that banks were immediately "scrambling" to entertain complaints after the open data implementation, and "roused" by its existence. However, these accounts may ultimately signify knee-jerk reactions to a controversial policy (Bloomberg 2013; Forbes 2013). To illustrate, other observers concluded that the CFPB and its open data initiative represented a "three-headed monster," potentially limiting consumer choice and fostering "confusing, unnecessarily duplicative, inconsistent, and open-ended" outcomes (Francis 2013). These reports broadly connote the significant resonance of the topic in the public eye, and this study provides an assessment with obvious implications on the role of the CFPB.

Consumer complaint reform has proved notoriously difficult across the financial industry, with media reports placing the sector of finance at the top of political campaign contributions in 2014 at about \$1.5 million per day (US News and World Report 2014). I observe one policy report calling attention to the importance of lobbying by the top 25 American banks (Drutman and Furnas 2013). I investigate a solution to the economic problem of consumer complaints, by investigating a potential relationship between the open data initiative of the CFPB and bank reactions as well as the behavioral aspects of consumer complaints. In so doing, I look at a new policy and its effect to break new ground on this specific topic of how to lessen the severity of bank complaints. The CFPB's own announcement of the open data initiative (CFPB 2011), serves as the main independent variable for the paper, although the only contact pursued with the CFPB during this research consisted of downloading relevant consumer complaint content from the CFPB webpage.

The willful blindness within some organizations with respect to how they treat customers and the desire for conformity within companies may be difficult to dislodge with public policy. Bénabou 
(2013) provides a relevant behavioral-economic model of the sense of denial that the paper shows is broken with online exposure. Transparency builds on adverse stimuli settings for non-forced compliance as noted in the negative reinforcement literature (Benartzi and Thaler 2013; Rabin 2013). The unique setting of financial market transparency allows me to quantify hesitation and accountability with respects to consumer complaints in the financial industry, which is novel to this context, perhaps due to its relative serecy. To illustrate, the European food industry has attempted similar reforms (Bavorová and Hirschauer 2012), which may benefit from similar study.

The discussion in this paper is linked to a swelling research agenda on income inequality. Recent and ongoing work in the inequality literature emphasize how policy makers can exploit social mobility distinctions to understand persistent changes in life trajectories (Ludwig, Duncan, Gennetian, Katz, Kessler, Kling, and Sanbonmatsu 2012; Chetty, Hendren, Kline, and Saez 2014; Chetty, Hendren and Katz 2016). Yet, there is surprisingly little to no discussion on any relationship with credit card channels (or with any financial product mechanisms for that matter), although the socially immobile may be relatively exposed to bankruptcy, a factor that may be one root cause of credit card harassment and related complaints. Individuals at the top levels of the social mobility distributions are similarly unstudied with respect to credit card complaint outcomes. I am able to investigate the relationship between being in the top and bottom parts of the social mobility distribution (as classified in the above literature), and credit card complaints, which I hope, furthers the discussion on income and wealth inequality. Open data provides a unique policy solution to incentivizing institutional change, a question that is understudied in the sphere of consumer complaint settings. In the results, I note that transparency motivates banks to treat their financial customers better.

The paper shows one way to potentially stymie a policy momentum since the 2008 finanical crisis toward the leadership of special interests in shaping US policy relative to the average citizen (Bartels 2008; Gilens 2012; Gilens and Page 2014; Bashir 2015). Credit card issuers are noted lobbyists of the US Congress, making transfers to influence policy action (Kitch 1990). A rational model of the lobbying process is provided in Bernheim and Whinston (1986). The paper provides empirical grounding. As a potential solution, a policy based on using open data to provoke surveillance may provide some bearing on such issues, even if surveillance policies are necessarily imperfect and might even come off as extreme, being a potentially mechanistic approach to making economic 
interactions more efficient (Browne 2015). The use of internet-based open data to reform financial companies, however, implies that surveillance may not be merely performed by a single actor whose ethics may be compromised, but potentially by a better-informed market.

\section{Concluding Comments}

This paper has used comprehensive data to describe how consumer complaints in the United States react to a new kind of reform based on a public database. An open data platform allowed individuals to provide their complaints to a third party, and banks become more likely to respond favorable to said concerns and exhibit a slight unwillingness to cause infractions after the open complaint data policy is in place.

In the findings, I have presented a description of how the credit card industry responded to an open data initiative relative to the excluded mortgage industry. I find that credit card providers became significantly more responsive to their clients in a positive way following this name-and-shame initiative. To contextualize the observed associations, I present parallel trends that show that credit card vendors did not anticipate the open data policy within the relatively stochastic environment of when infringements were caused for consumers. Companies were generally likely to cause infractions nearly two days later when the open data policy was implemented, implying that they were generally hesitant to allow such situations to occur, or potentially nervous about their possibility. The delayed causes for complaints can also be explained as companies being more time-inconsistent in terms of inconveniencing their customers. This sensitiveness in the credit card industry relative to the mortgage industry has slightly sobering implications in that they appear to accure to the average individual in the United States, but not necessarily those who are benefitting or suffering from economic inequality. Perhaps policies that attack the problem from the consumer side might be complementary, although such approaches might require some sensitivity on the part of policy makers to resist the temptation to relieve companies of any responsibility. The CFPB was created to play an important role in the erstwhile Obama Administration. While I hope to have shown that open data has a surprisingly significant role to play in financial reform, transparency policies cannot be a panacea to enact political outcomes: the reductions in customer mistreatment I observe still leave 
a role for litigation and other standard measures, and I view such instruments as complementary. The potential role of transparency in other political foundations of the economy may also be worth addressing in future research. 
Figure 1: TOTAL COMPANy COMPlainTS FROM DECEMBER 2011 TO MARCH 2013

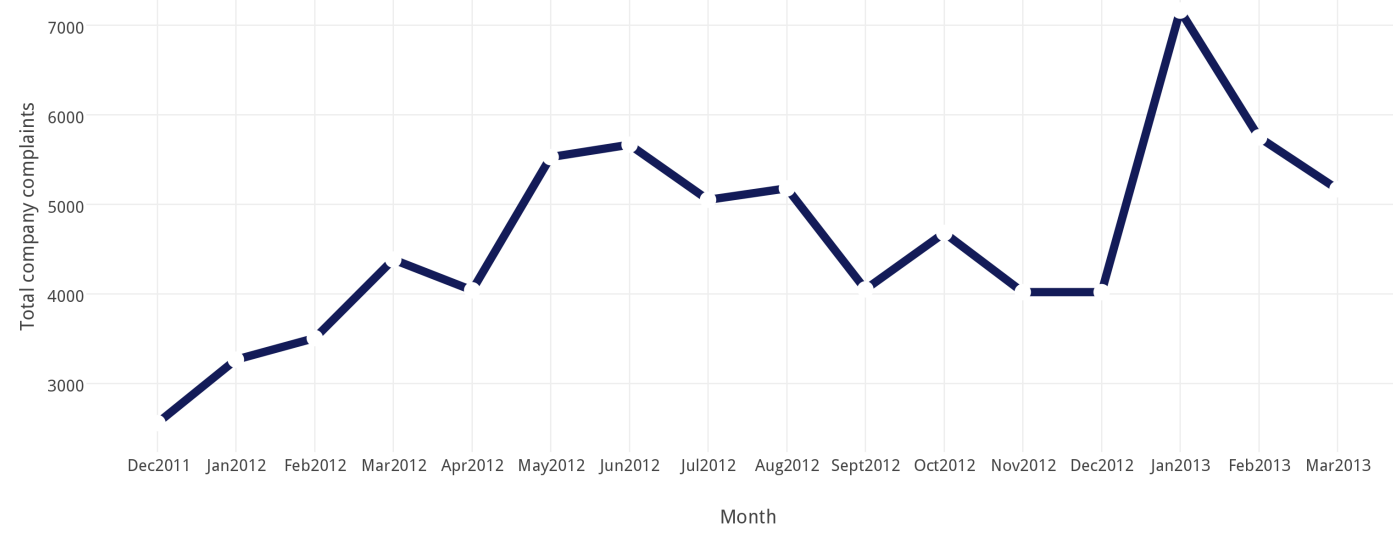

Figure 2: Complaints From Open Versus Closed Data Broken Down By

SUBMISSION MECHANISM

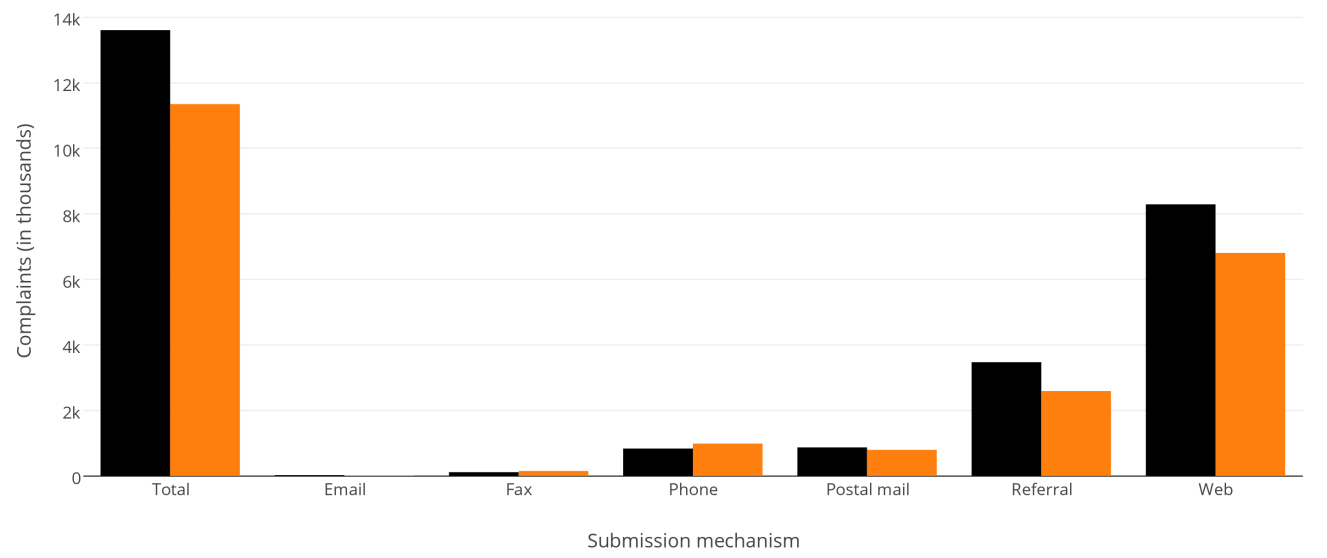

- No Open Data

Open Data 


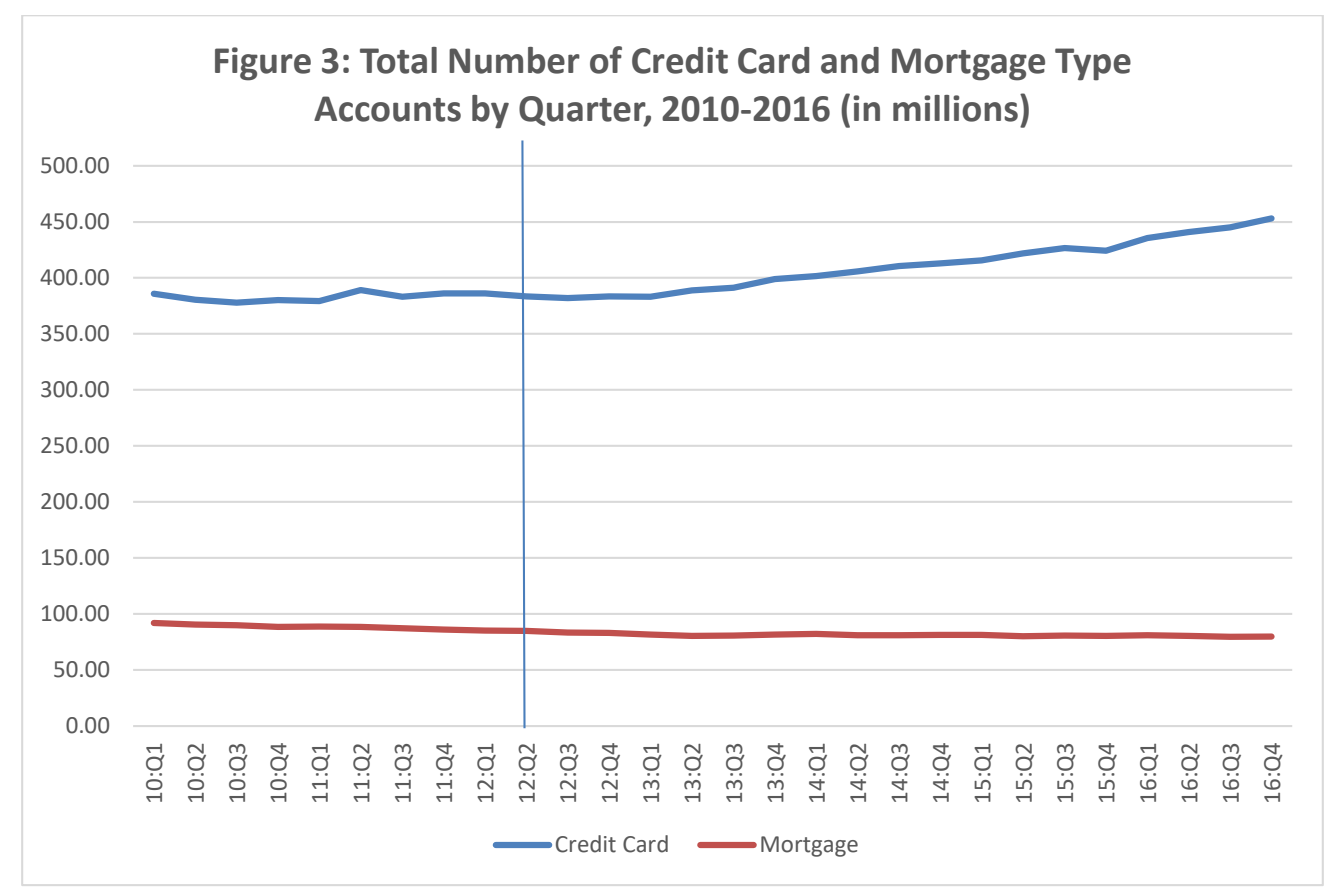

Source: Federal Reserve Bank of New York. The chart shows total number of credit card and total number of mortgage accounts in the United States, from 2010 to 2016 . The vertical line shows the timing of the open data policy in June (the second quarter) of 2012. 


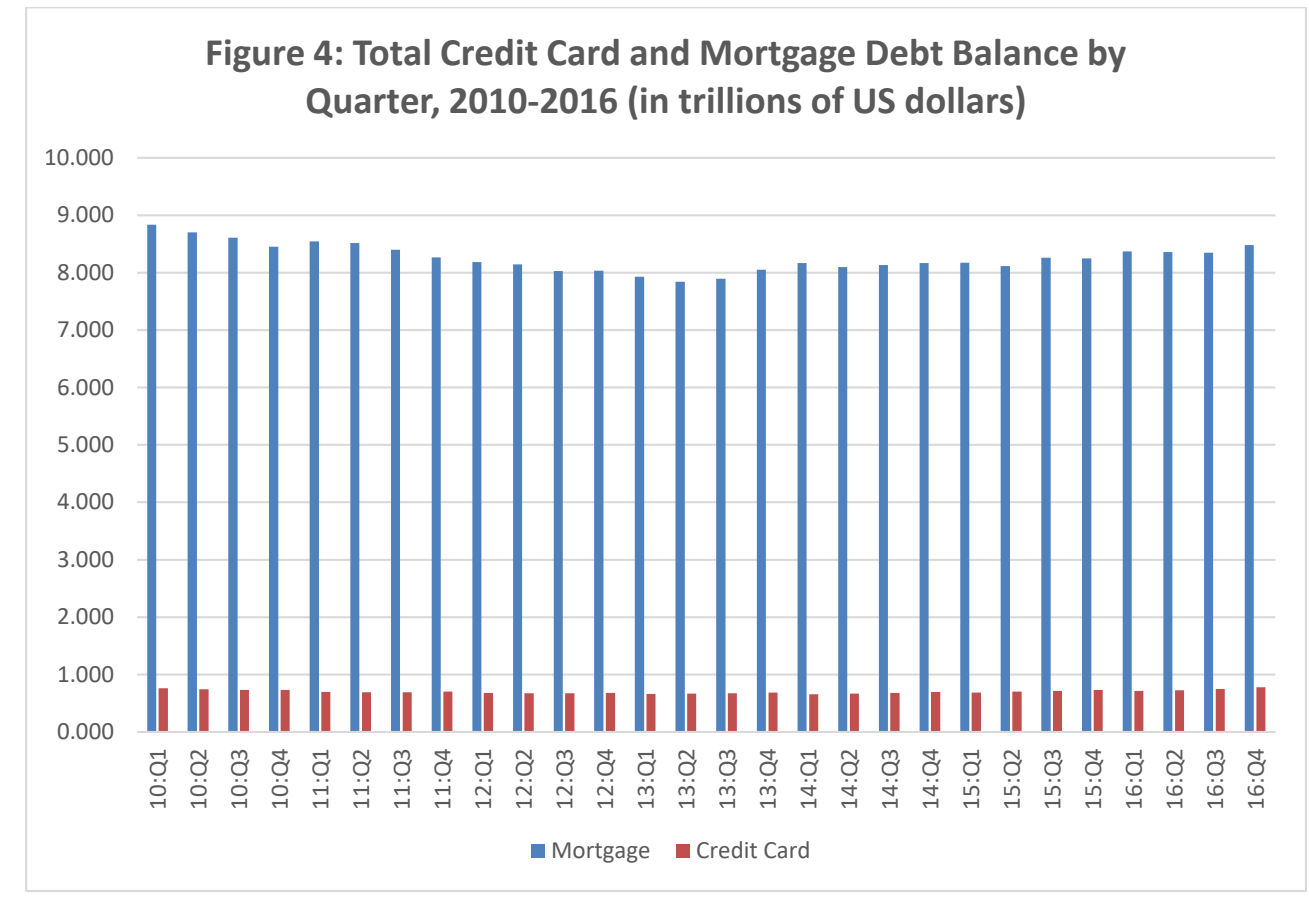

Source: Federal Reserve Bank of New York. The chart shows total debt balance of credit card and total number of mortgage accounts in the United States, from 2010 to 2016. 
Table 1: Summary Statistics

\begin{tabular}{|l|l|l|l|l|l|}
\hline Variable & $\mathbf{N}$ & Mean & Std. Dev. & Min & Max \\
\hline APR or interest rate & 74244 & .0282582 & .1657107 & 0 & 1 \\
\hline Advertising and marketing & 74244 & .006317 & .0792287 & 0 & 1 \\
\hline $\begin{array}{l}\text { Application processing } \\
\text { delay }\end{array}$ & 74244 & .0015894 & .0398353 & 0 & 1 \\
\hline $\begin{array}{l}\text { Application, originator, } \\
\text { mortgage broker }\end{array}$ & 74244 & .0502128 & .2183853 & 0 & 1 \\
\hline Arbitration & 74244 & .0008486 & .0291178 & 0 & 1 \\
\hline Balance transfer & 74244 & .0032865 & .0572338 & 0 & 1 \\
\hline Balance transfer fee & 74244 & .0007273 & .0269595 & 0 & 1 \\
\hline Bankruptcy & 74244 & .0011988 & .0346024 & 0 & 1 \\
\hline Billing disputes & 74244 & .042064 & .2007366 & 0 & 1 \\
\hline Billing statement & 74244 & .0075831 & .0867508 & 0 & 1 \\
\hline Cash advance & 74244 & .0009024 & .0300271 & 0 & 1 \\
\hline Cash advance fee & 74244 & .0007543 & .0274538 & 0 & 1 \\
\hline Closing/Cancelling account & 74244 & .0173078 & .1304165 & 0 & 1 \\
\hline Collection debt dispute & 74244 & .0101961 & .1004604 & 0 & 1 \\
\hline Collection practices & 74244 & .011772 & .107859 & 0 & 1 \\
\hline Convenience checks & 74244 & .0004984 & .0223185 & 0 & 1 \\
\hline $\begin{array}{l}\text { Credit card } \\
\text { protection/debt protection }\end{array}$ & 74244 & .0099537 & .099271 & 0 & 1 \\
\hline $\begin{array}{l}\text { Credit } \\
\text { decision/underwriting }\end{array}$ & 74244 & .0155568 & .1237538 & & 1 \\
\hline Credit determination & 74244 & .0091859 & .0954027 & 0 & 1 \\
\hline $\begin{array}{l}\text { Credit line } \\
\text { increase/decrease }\end{array}$ & 74244 & .0081892 & .0901236 & 0 & 1 \\
\hline Credit reporting & 74244 & .0213889 & .144678 & 0 & 1 \\
\hline $\begin{array}{l}\text { Customer } \\
\text { service/Customer relations }\end{array}$ & 74244 & .0068288 & .0823547 & 0 & 1 \\
\hline Delinquent account & 74244 & .0032326 & .0567642 & 0 & 1 \\
\hline $\begin{array}{l}\text { Forbearance/Workout } \\
\text { plans }\end{array}$ & 74244 & .0025995 & .0509197 & 0 & 1 \\
\hline $\begin{array}{l}\text { Identity } \\
\text { theft/Fraud/Embezzlement }\end{array}$ & 74244 & .0181159 & .1333716 & 0 & 1 \\
\hline Late fee & 74244 & .0112198 & .1053282 & 0 & 1 \\
\hline $\begin{array}{l}\text { Loan modification, } \\
\text { collection, foreclosure }\end{array}$ & 74244 & .4380017 & .4961447 & 0 & 1 \\
\hline $\begin{array}{l}\text { Loan servicing, payments, } \\
\text { escrow account }\end{array}$ & 74244 & .1785329 & .3829633 & 0 & 1 \\
\hline Other & 74244 & .036178 & .1867341 & 0 & 1 \\
\hline Other fee & .0073003 & .0851296 & 0 & 1 \\
\hline
\end{tabular}




\begin{tabular}{|l|l|l|l|l|l|}
\hline Over limit fee & 74244 & .0008351 & .028886 & 0 & 1 \\
\hline Payoff process & 74244 & .0079468 & .0887903 & 0 & 1 \\
\hline Privacy & 74244 & .0012257 & .0349886 & 0 & 1 \\
\hline Rewards & 74244 & .0063439 & .0793964 & 0 & 1 \\
\hline Sale of account & 74244 & .00066 & .0256819 & 0 & 1 \\
\hline $\begin{array}{l}\text { Settlement process and } \\
\text { costs }\end{array}$ & 74244 & .0241097 & .1533908 & 0 & 1 \\
\hline Transaction issue & 74244 & .0058456 & .0762332 & 0 & 1 \\
\hline $\begin{array}{l}\text { Unsolicited issue of credit } \\
\text { card }\end{array}$ & 74244 & .0032326 & .0567642 & 0 & 1 \\
\hline Submitted by email & 74244 & .0021146 & .045937 & 0 & 1 \\
\hline Submitted by fax & 74244 & .0158935 & .1250646 & 0 & 1 \\
\hline Submitted by phone & 74244 & .0705512 & .2560753 & 0 & 1 \\
\hline Submitted by postal mail & 74244 & .0645035 & .2456494 & 0 & 1 \\
\hline Submitted by referral & 74244 & .3818894 & .4858529 & 0 & 1 \\
\hline Submitted by web & 74244 & .4650477 & .4987802 & 0 & 1 \\
\hline $\begin{array}{l}\text { OD: Open Data (complaint } \\
\text { received after June 19, }\end{array}$ & 74244 & .1529012 & .3598947 & 0 & 1 \\
\hline 2012) & & & & .250 & 1 \\
\hline CC: Credit Card complaint & 74244 & .2708502 & .4444019 & 0 & 1 \\
\hline Mortgage complaint & 74244 & .7291498 & .4444019 & 0 & 1 \\
\hline Company response: closed & 74244 & .0214024 & .1447226 & 0 & 1 \\
\hline $\begin{array}{l}\text { Company response: closed } \\
\text { with explanation }\end{array}$ & 74244 & .5506573 & .4974306 & 0 & 1 \\
\hline $\begin{array}{l}\text { Company response: closed } \\
\text { with monetary relief }\end{array}$ & 74244 & .0683422 & .2523339 & 0 & 1 \\
\hline $\begin{array}{l}\text { Company response: closed } \\
\text { with non-monetary relief }\end{array}$ & 74244 & .1005199 & .300694 & 0 & 1 \\
\hline $\begin{array}{l}\text { Company response: closed } \\
\text { with relief }\end{array}$ & 74244 & .0528258 & .2236871 & 0 & 1 \\
\hline $\begin{array}{l}\text { Company response: closed } \\
\text { without relief }\end{array}$ & 74244 & .2016863 & .4012619 & 0 & 1 \\
\hline Untimely response & 74244 & .004566 & .0674184 & 0 & 1 \\
\hline Day of the month received & 74244 & 15.54771 & 8.605184 & 1 & 31 \\
\hline Day sent to company & 74244 & 15.94406 & 8.579561 & 1 & 31 \\
\hline $\begin{array}{l}\text { Consumer disputed } \\
\text { company response }\end{array}$ & 73126 & .2269371 & .4188544 & 0 & 1 \\
\hline
\end{tabular}

Notes: Source: Consumer Financial Protection Bureau. 
Table 2. Open Data and Company Response - Complaints Closed

\begin{tabular}{|c|c|c|c|c|c|}
\hline $\begin{array}{l}\text { Dep. Var.: Complaint } \\
\text { closed }\end{array}$ & (1) & (2) & (3) & (4) & (5) \\
\hline Open Data & $\begin{array}{c}0.01^{* * *} \\
(0.002)\end{array}$ & $\begin{array}{c}0.01^{* * *} \\
(0.002)\end{array}$ & $\begin{array}{c}0.01 * * * \\
(0.002)\end{array}$ & $\begin{array}{c}0.006^{* *} \\
(0.002)\end{array}$ & $\begin{array}{c}0.006 * * \\
(0.002)\end{array}$ \\
\hline Credit card & $\begin{array}{c}-0.02 * * * \\
(0.001)\end{array}$ & $\begin{array}{c}-0.04 * * * \\
(0.01)\end{array}$ & $\begin{array}{c}-0.03 * * \\
(0.01)\end{array}$ & $\begin{array}{c}-0.03^{* *} \\
(0.01)\end{array}$ & $\begin{array}{c}-0.029^{* *} \\
(0.01)\end{array}$ \\
\hline Military & & $\begin{array}{c}-0.02 * * * \\
(0.001)\end{array}$ & $\begin{array}{c}-0.018^{* * *} \\
(0.001)\end{array}$ & $\begin{array}{c}-0.018^{* * *} \\
(0.001)\end{array}$ & $\begin{array}{c}-0.018^{* * *} \\
(0.001)\end{array}$ \\
\hline Submitted by email & & & $\begin{array}{l}0.003 \\
(0.01)\end{array}$ & $\begin{array}{l}0.003 \\
(0.01)\end{array}$ & $\begin{array}{l}0.003 \\
(0.01)\end{array}$ \\
\hline Submitted by fax & & & $\begin{array}{l}0 \\
\text { (.) }\end{array}$ & $\begin{array}{c}0 \\
(.)\end{array}$ & $\begin{array}{c}0 \\
(.)\end{array}$ \\
\hline Submitted by phone & & & $\begin{array}{l}-0.001 \\
(0.01)\end{array}$ & $\begin{array}{r}-0.001 \\
(0.01)\end{array}$ & $\begin{array}{l}-0.001 \\
(0.01)\end{array}$ \\
\hline Submitted by postal mail & & & $\begin{array}{l}0.003 \\
(0.01)\end{array}$ & $\begin{array}{l}0.003 \\
(0.01)\end{array}$ & $\begin{array}{l}0.003 \\
(0.01)\end{array}$ \\
\hline Submitted by referral & & & $\begin{array}{l}0.005 \\
(0.01)\end{array}$ & $\begin{array}{l}0.006 \\
(0.01)\end{array}$ & $\begin{array}{l}0.006 \\
(0.01)\end{array}$ \\
\hline Submitted by web & & & $\begin{array}{l}-0.001 \\
(0.01)\end{array}$ & $\begin{array}{l}-0.001 \\
(0.01)\end{array}$ & $\begin{array}{r}-0.001 \\
(0.01)\end{array}$ \\
\hline $\begin{array}{l}\text { Include } \\
\text { year dummies? }\end{array}$ & No & No & No & Yes & Yes \\
\hline $\begin{array}{l}\text { Include the } 37 \text { complaint } \\
\text { issue dummies? } \\
\text { Include company } \\
\text { dummies for above- } \\
\text { average complaints? }\end{array}$ & No & Yes & Yes & Yes & Yes \\
\hline$R^{2}$ & 0.002 & 0.003 & 0.004 & 0.004 & 0.005 \\
\hline $\mathrm{N}$ & 73525 & 73525 & 73525 & 73525 & 73525 \\
\hline
\end{tabular}


Table 3: Open Data and Company Responses - Complaints Closed with Explanation

\begin{tabular}{|c|c|c|c|c|c|}
\hline & (1) & (2) & (3) & (4) & (5) \\
\hline Open Data & $\begin{array}{c}0.46^{* * *} \\
(0.01)\end{array}$ & $\begin{array}{c}0.46^{* * *} \\
(0.01)\end{array}$ & $\begin{array}{c}0.45^{* * *} \\
(0.01)\end{array}$ & $\begin{array}{c}0.33^{* * *} \\
(0.01)\end{array}$ & $\begin{array}{c}0.33^{* * *} \\
(0.01)\end{array}$ \\
\hline Credit card & $\begin{array}{c}-0.50^{* * *} \\
(0.01)\end{array}$ & $\begin{array}{c}-0.652^{* * *} \\
(0.02)\end{array}$ & $\begin{array}{c}-0.604^{* * *} \\
(0.03)\end{array}$ & $\begin{array}{c}-0.510^{* * *} \\
(0.02)\end{array}$ & $\begin{array}{c}-0.488^{* * *} \\
(0.02)\end{array}$ \\
\hline \multicolumn{2}{|l|}{ Military } & $\begin{array}{c}-0.11^{*} \\
(0.05)\end{array}$ & $\begin{array}{c}-0.11^{*} \\
(0.04)\end{array}$ & $\begin{array}{c}-0.11 \\
(0.06)\end{array}$ & $\begin{array}{c}-0.102 \\
(0.06)\end{array}$ \\
\hline \multicolumn{2}{|c|}{ Submitted by email } & & $\begin{array}{c}-0.23^{* * * *} \\
(0.05)\end{array}$ & $\begin{array}{c}-0.18^{* *} \\
(0.05)\end{array}$ & $\begin{array}{c}-0.19 * * * \\
(0.05)\end{array}$ \\
\hline \multicolumn{2}{|c|}{ Submitted by fax } & & $\begin{array}{c}0 \\
(.)\end{array}$ & $\begin{array}{c}0 \\
\text { (.) }\end{array}$ & $\begin{array}{c}0 \\
(.)\end{array}$ \\
\hline \multicolumn{2}{|c|}{ Submitted by phone } & & $\begin{array}{c}-0.15^{* *} \\
(0.05)\end{array}$ & $\begin{array}{l}0.129 * \\
(0.05)\end{array}$ & $\begin{array}{c}-0.128^{*} \\
(0.05)\end{array}$ \\
\hline \multicolumn{2}{|c|}{ Submitted by postal mail } & & $\begin{array}{l}-0.07 \\
(0.05)\end{array}$ & $\begin{array}{c}-0.05 \\
(0.04)\end{array}$ & $\begin{array}{l}-0.05 \\
(0.04)\end{array}$ \\
\hline \multicolumn{2}{|c|}{ Submitted by referral } & & $\begin{array}{c}-0.16^{* *} \\
(0.05)\end{array}$ & $\begin{array}{c}-0.14 * * \\
(0.05)\end{array}$ & $\begin{array}{c}-0.14^{* *} \\
(0.05)\end{array}$ \\
\hline \multicolumn{2}{|c|}{ Submitted by web } & & $\begin{array}{c}-0.147^{* *} \\
(0.05)\end{array}$ & $\begin{array}{c}-0.134 * * \\
(0.05)\end{array}$ & $\begin{array}{c}-0.132^{* *} \\
(0.05)\end{array}$ \\
\hline \multicolumn{5}{|l|}{ Include year } & Yes \\
\hline \multicolumn{6}{|c|}{ Include 37 complaint } \\
\hline \multicolumn{6}{|l|}{$\begin{array}{l}\text { Include } \\
\text { company } \\
\text { dummies } \\
\text { for high }\end{array}$} \\
\hline $\begin{array}{l}\text { complaints? } \\
\mathrm{R}^{2}\end{array}$ & $\begin{array}{c}\text { No } \\
0.102\end{array}$ & $\begin{array}{l}\text { No } \\
0.112\end{array}$ & $\begin{array}{l}\text { No } \\
0.115\end{array}$ & $\begin{array}{l}\text { No } \\
0.174\end{array}$ & $\begin{array}{c}\text { Yes } \\
0.179\end{array}$ \\
\hline$N$ & 73525 & 73525 & 73525 & 73525 & 73525 \\
\hline
\end{tabular}

Notes: Source: Consumer Financial Protection Bureau. Robust standard errors clustered the state level, including military states. OLS regressions include submission mechanism-, issue-, company, and year-related dummy variables. Significance levels: ${ }^{* * *} p<0.01,{ }^{* *} p<0.05,{ }^{*}$ $\mathrm{p}<0.1$. 
Table 4: Open Data and Company Responses - Complaints Closed with Monetary Relief

\begin{tabular}{|c|c|c|c|c|c|}
\hline & (1) & (2) & (3) & (4) & (5) \\
\hline \multirow[t]{2}{*}{ Open Data } & $0.22 * * *$ & $0.225^{* * *}$ & $0.225^{* * *}$ & $0.219 * * *$ & $0.219 * * *$ \\
\hline & $(0.01)$ & $(0.01)$ & $(0.01)$ & $(0.01)$ & $(0.01)$ \\
\hline \multirow[t]{2}{*}{ Credit Card } & $0.027^{* * *}$ & $0.021 *$ & 0.014 & $0.020^{*}$ & $0.02^{*}$ \\
\hline & $(0.003)$ & $(0.01)$ & $(0.01)$ & $(0.01)$ & $(0.01)$ \\
\hline \multirow{2}{*}{\multicolumn{2}{|c|}{ Military }} & $0.016 * *$ & $0.014^{*}$ & $0.012^{*}$ & 0.013 \\
\hline & & $(0.01)$ & $(0.01)$ & $(0.01)$ & $(0.01)$ \\
\hline \multirow{2}{*}{\multicolumn{2}{|c|}{ Submitted by Email }} & & -0.005 & -0.003 & -0.003 \\
\hline & & & $(0.02)$ & $(0.02)$ & $(0.02)$ \\
\hline \multirow{2}{*}{\multicolumn{2}{|c|}{ Submitted by Fax }} & & 0 & 0 & 0 \\
\hline & & & (.) & (.) & (.) \\
\hline \multirow{2}{*}{\multicolumn{2}{|c|}{ Submitted by Phone }} & & 0.001 & 0.002 & 0.002 \\
\hline & & & $(0.01)$ & $(0.01)$ & $(0.01)$ \\
\hline \multicolumn{6}{|c|}{ Submitted by Postal } \\
\hline \multirow[t]{2}{*}{ Mail } & & & -0.005 & -0.005 & -0.005 \\
\hline & & & $(0.01)$ & $(0.01)$ & $(0.01)$ \\
\hline \multirow{2}{*}{\multicolumn{2}{|c|}{ Submitted by Referral }} & & 0.005 & 0.005 & 0.005 \\
\hline & & & $(0.01)$ & $(0.01)$ & $(0.01)$ \\
\hline \multirow{2}{*}{\multicolumn{2}{|c|}{ Submitted by Web }} & & 0.008 & 0.009 & 0.009 \\
\hline & & & $(0.01)$ & $(0.01)$ & $(0.01)$ \\
\hline \multicolumn{6}{|l|}{ Include year } \\
\hline dummies? & No & No & No & Yes & Yes \\
\hline \multicolumn{6}{|c|}{ Include 37 complaint } \\
\hline issues? & No & Yes & Yes & Yes & Yes \\
\hline \multirow{3}{*}{\multicolumn{6}{|c|}{$\begin{array}{l}\text { Include } \\
\text { company } \\
\text { dummies } \\
\text { for high }\end{array}$}} \\
\hline & & & & & \\
\hline & & & & & \\
\hline $\begin{array}{l}\text { for high } \\
\text { complaints? }\end{array}$ & No & No & No & No & Yes \\
\hline $\mathrm{R}^{2}$ & 0.126 & 0.168 & 0.168 & 0.169 & 0.169 \\
\hline$N$ & 73525 & 73525 & 73525 & 73525 & 73525 \\
\hline
\end{tabular}

Notes: Source: Consumer Financial Protection Bureau. Robust standard errors clustered at the state level, including military states. OLS regressions include submission mechanism-, issue-, company, and year-related dummy variables. Significance levels: ${ }^{* * *} p<0.01,{ }^{* *} p<0.05,{ }^{*}$ $p<0.1$. 
Table 5: Open Data and Company Responses - Complaints Closed with Non-Monetary Relief

\begin{tabular}{|c|c|c|c|c|c|c|}
\hline \multirow{2}{*}{ Open Data } & \multicolumn{2}{|c|}{ (1) } & (2) & (3) & (4) & (5) \\
\hline & \multicolumn{2}{|c|}{$\begin{array}{c}0.100^{* * *} \\
(0.003)\end{array}$} & $\begin{array}{c}0.098^{* * *} \\
(0.003)\end{array}$ & $\begin{array}{c}0.100^{* * *} \\
(0.003)\end{array}$ & $\begin{array}{c}0.090^{* * *} \\
(0.003)\end{array}$ & $\begin{array}{c}0.089 * * * \\
(0.003)\end{array}$ \\
\hline Credit card & \multicolumn{2}{|c|}{$-0.072 * * *$} & $\begin{array}{c}-0.076^{* * *} \\
(0.02)\end{array}$ & $\begin{array}{l}-0.07 \\
(0.02)\end{array}$ & $\begin{array}{c}-0.06^{*} \\
(0.02)\end{array}$ & $\begin{array}{c}-0.07^{* * *} \\
(0.02)\end{array}$ \\
\hline \multicolumn{3}{|l|}{ Military } & $\begin{array}{c}0.135 * * * \\
(0.02)\end{array}$ & $\begin{array}{l}0.139^{*} \\
(0.02)\end{array}$ & $\begin{array}{c}0.137^{* * *} \\
(0.02)\end{array}$ & $\begin{array}{c}0.134^{* * *} \\
(0.02)\end{array}$ \\
\hline \multicolumn{3}{|c|}{ Submitted by Email } & & $\begin{array}{l}-0.017 \\
(0.02)\end{array}$ & $\begin{array}{c}-0.014 \\
(0.02)\end{array}$ & $\begin{array}{l}-0.007 \\
(0.02)\end{array}$ \\
\hline \multicolumn{3}{|c|}{ Submitted by Fax } & & $\begin{array}{l}0 \\
\text { (.) }\end{array}$ & $\begin{array}{l}0 \\
(.)\end{array}$ & $\begin{array}{c}0 \\
\text { (.) }\end{array}$ \\
\hline \multicolumn{3}{|c|}{ Submitted by Phone } & & $\begin{array}{c}0.031^{* *} \\
(0.01)\end{array}$ & $\begin{array}{c}0.033^{* *} \\
(0.01)\end{array}$ & $\begin{array}{c}0.032^{* *} \\
(0.01)\end{array}$ \\
\hline \multicolumn{3}{|c|}{ Submitted by Postal mail } & & $\begin{array}{c}0.038^{* * *} \\
(0.01)\end{array}$ & $\begin{array}{c}0.038^{* * *} \\
(0.01)\end{array}$ & $\begin{array}{c}0.039 * * * \\
(0.01)\end{array}$ \\
\hline \multicolumn{3}{|c|}{ Submitted by Referral } & & $\begin{array}{c}0.045^{* * *} \\
(0.01)\end{array}$ & $\begin{array}{c}0.046^{* * *} \\
(0.01)\end{array}$ & $\begin{array}{c}0.043^{* * *} \\
(0.01)\end{array}$ \\
\hline \multicolumn{3}{|c|}{ Submitted by Fax } & & $\begin{array}{c}0.028^{*} \\
(0.01)\end{array}$ & $\begin{array}{c}0.029^{*} \\
(0.01)\end{array}$ & $\begin{array}{c}0.028^{*} \\
(0.01)\end{array}$ \\
\hline \multicolumn{3}{|c|}{ Include } & No & No & Yes & Yes \\
\hline $\begin{array}{l}\text { Include } 37 \\
\text { complaint iss }\end{array}$ & & No & Yes & Yes & Yes & Yes \\
\hline $\mathrm{R}^{2}$ & & 0.008 & 0.015 & 0.016 & 0.017 & 0.021 \\
\hline $\mathrm{N}$ & & 73525 & 73525 & 73525 & 73525 & 73525 \\
\hline
\end{tabular}

Notes: Source: Consumer Financial Protection Bureau. Robust standard errors clustered at the state level, including military states. OLS regressions include submission mechanism-, issue-, company, and year-related dummy variables. Significance levels: ${ }^{* * *} \mathrm{p}<0.01,{ }^{* *} \mathrm{p}<0.05,{ }^{*}$ $p<0.1$. 
Table 6. Open Data and Company Response - Untimely Response

\begin{tabular}{|c|c|c|c|c|c|}
\hline & (1) & (2) & (3) & (4) & (5) \\
\hline Open Data & $\begin{array}{c}-0.008^{* * *} \\
(0.001)\end{array}$ & $\begin{array}{r}-0.008^{* * *} \\
(0.001)\end{array}$ & $\begin{array}{c}-0.008^{* * *} \\
(0.001)\end{array}$ & $\begin{array}{c}-0.004^{* * *} \\
(0.001)\end{array}$ & $\begin{array}{c}-0.004^{* * *} \\
(0.001)\end{array}$ \\
\hline Credit card & $\begin{array}{c}0.003^{* * *} \\
(0.001)\end{array}$ & $\begin{array}{r}0.009 * * * \\
(0.002)\end{array}$ & $\begin{array}{c}0.008^{* * *} \\
(0.002)\end{array}$ & $\begin{array}{l}0.005^{*} \\
(0.002)\end{array}$ & $\begin{array}{l}0.005^{*} \\
(0.002)\end{array}$ \\
\hline \multicolumn{2}{|l|}{ Military } & $\begin{array}{r}0.031 \\
(0.03)\end{array}$ & $\begin{array}{l}0.031 \\
(0.03)\end{array}$ & $\begin{array}{l}0.031 \\
(0.03)\end{array}$ & $\begin{array}{l}0.031 \\
(0.03)\end{array}$ \\
\hline \multicolumn{2}{|c|}{ Submitted by email } & & $\begin{array}{l}0.014 \\
(0.01)\end{array}$ & $\begin{array}{l}0.012 \\
(0.01)\end{array}$ & $\begin{array}{l}0.012 \\
(0.01)\end{array}$ \\
\hline \multicolumn{2}{|c|}{ Submitted by fax } & & $\begin{array}{c}0 \\
(.)\end{array}$ & $\begin{array}{c}0 \\
(.)\end{array}$ & $\begin{array}{c}0 \\
\text { (.) }\end{array}$ \\
\hline \multicolumn{2}{|c|}{ Submitted by Phone } & & $\begin{array}{c}0.003^{* *} \\
(0.001)\end{array}$ & $\begin{array}{l}0.002^{*} \\
(0.001)\end{array}$ & $\begin{array}{c}0.002 \\
(0.001)\end{array}$ \\
\hline \multicolumn{2}{|c|}{ Submitted by Postal Mail } & & $\begin{array}{c}0.002 \\
(0.001)\end{array}$ & $\begin{array}{c}0.002 \\
(0.001)\end{array}$ & $\begin{array}{c}0.002 \\
(0.001)\end{array}$ \\
\hline \multicolumn{2}{|c|}{ Submitted by Referral } & & $\begin{array}{c}0.005^{* * *} \\
(0.001)\end{array}$ & $\begin{array}{c}0.004^{* * *} \\
(0.001)\end{array}$ & $\begin{array}{c}0.004^{* * *} \\
(0.001)\end{array}$ \\
\hline \multicolumn{2}{|c|}{ Submitted by Web } & & $\begin{array}{c}0.003^{* * *} \\
(0.001)\end{array}$ & $\begin{array}{c}0.003^{* * *} \\
(0.001)\end{array}$ & $\begin{array}{c}0.003^{* * *} \\
(0.001)\end{array}$ \\
\hline \multicolumn{6}{|l|}{$\begin{array}{l}\text { Include year } \\
\text { dummies? }\end{array}$} \\
\hline & No & No & No & Yes & Yes \\
\hline \multicolumn{5}{|c|}{ Include 37 complaint } & Yes \\
\hline $\mathrm{R}^{2}$ & 0.001 & 0.002 & 0.002 & 0.004 & 0.004 \\
\hline $\mathrm{N}$ & 73525 & 73525 & 73525 & 73525 & 73525 \\
\hline
\end{tabular}

Notes: Source: Consumer Financial Protection Bureau. Robust standard errors clustered the state level, including military states. OLS regressions include submission mechanism-, issue-, company, and year-related dummy variables. Significance levels: ${ }^{* * *} p<0.01,{ }^{* *} p<0.05,{ }^{*}$ $p<0.1$. 
Table 7: Parallel Trends Validation from Effect of credit card on days complaints were reported prior to open data policy

\begin{tabular}{|c|c|c|c|c|c|}
\hline $\begin{array}{l}\text { Dependent variable: day } \\
\text { complaint was received }\end{array}$ & & & & & \\
\hline Panel A: Complaint Issues & (1) & $(2)$ & (3) & (4) & (5) \\
\hline Credit card & 1.459 & 1.459 & 1.265 & 1.356 & 1.315 \\
\hline & $(1.65)$ & $(1.65)$ & (1.5) & (1.5) & $(1.5)$ \\
\hline APR/interest & -0.499 & -0.499 & -0.511 & -0.537 & -0.54 \\
\hline & $(0.85)$ & $(0.85)$ & $(0.84)$ & $(0.84)$ & $(0.84)$ \\
\hline Advertising/marketing & -0.028 & -0.028 & -0.082 & -0.032 & -0.038 \\
\hline & $(1.03)$ & $(1.03)$ & $(1.02)$ & $(1.01)$ & $(1.01)$ \\
\hline Application processing & -2.383 & -2.383 & -2.336 & -2.247 & -2.237 \\
\hline delay & (1.39) & (1.39) & $(1.37)$ & $(1.38)$ & (1.38) \\
\hline Application originator & & & & & \\
\hline /mortgage broker & 2.319 & 2.319 & 2.099 & 2.211 & 2.207 \\
\hline & $(1.76)$ & $(1.76)$ & $(1.65)$ & $(1.65)$ & (1.65) \\
\hline Arbitration & 0.099 & 0.099 & 0.059 & -0.052 & -0.06 \\
\hline & $(2.24)$ & $(2.24)$ & $(2.24)$ & $(2.22)$ & $(2.22)$ \\
\hline Balance transfer & -0.177 & -0.177 & -0.211 & -0.179 & 0.171 \\
\hline & $(1.29)$ & (1.29) & $(1.27)$ & $(1.27)$ & (1.27) \\
\hline Balance transfer fee & -0.813 & -0.813 & -0.823 & -0.777 & -0.773 \\
\hline & $(1.76)$ & $(1.76)$ & $(1.75)$ & $(1.73)$ & (1.73) \\
\hline Bankruptcy & 0.639 & 0.639 & 0.597 & 0.517 & 0.522 \\
\hline & $(1.83)$ & $(1.83)$ & $(1.83)$ & (1.79) & $(1.78)$ \\
\hline Billing disputes & -0.427 & -0.427 & -0.422 & -0.421 & -0.421 \\
\hline & $(0.81)$ & $(0.81)$ & $(0.81)$ & $(0.8)$ & $(0.8)$ \\
\hline Billing statement & -1.18 & -1.18 & -1.17 & -1.15 & -1.151 \\
\hline & $(0.97)$ & $(0.97)$ & $(0.97)$ & $(0.95)$ & $(0.95)$ \\
\hline Cash advance & -0.859 & -0.859 & -0.781 & -0.919 & -0.915 \\
\hline & $(1.67)$ & $(1.67)$ & (1.67) & $(1.66)$ & $(1.66)$ \\
\hline Cash advance fee & 0.368 & 0.368 & 0.343 & 0.293 & 0.285 \\
\hline & $(1.25)$ & $(1.25)$ & (1.24) & (1.23) & (1.23) \\
\hline Closing/cancelling account & -0.253 & -0.253 & -0.263 & -0.265 & -0.267 \\
\hline & $(0.82)$ & $\langle 0.82\rangle$ & $(0.83)$ & $(0.81)$ & $(0.81)$ \\
\hline Collection debt dispute & -0.101 & -0.102 & -0.112 & -0.143 & -0.146 \\
\hline & $(0.89)$ & (0.89) & $(0.9)$ & $(0.89)$ & $(0.89)$ \\
\hline Collection practices & -0.371 & -0.371 & -0.368 & -0.373 & -0.374 \\
\hline & $(0.87)$ & $(0.87)$ & $(0.88)$ & $(0.86)$ & $(0.86)$ \\
\hline Convenience checks & 0.344 & 0.344 & 0.405 & 0.372 & 0.364 \\
\hline & (1.46) & (1.46) & (1.41) & (1.38) & (1.38) \\
\hline
\end{tabular}




\begin{tabular}{|c|c|c|c|c|c|}
\hline $\begin{array}{l}\text { Credit card protection/debt } \\
\text { protection }\end{array}$ & $\begin{array}{l}0.681 \\
(0.92)\end{array}$ & $\begin{array}{l}0.681 \\
(0.92)\end{array}$ & $\begin{array}{l}0.664 \\
(0.92)\end{array}$ & $\begin{array}{r}0.646 \\
(0.9)\end{array}$ & $\begin{array}{l}0.645 \\
(0.9)\end{array}$ \\
\hline \multicolumn{6}{|l|}{ Credit } \\
\hline decision/underwriting & $\begin{array}{r}2.139 \\
(1.72)\end{array}$ & $\begin{array}{r}2.139 \\
(1.72)\end{array}$ & $\begin{array}{r}1.913 \\
(1.61)\end{array}$ & $\begin{array}{r}2.026 \\
(1.61)\end{array}$ & $\begin{array}{l}2.013 \\
(1.61)\end{array}$ \\
\hline Credit determination & $\begin{array}{r}-0.363 \\
(0.89)\end{array}$ & $\begin{array}{r}-0.363 \\
(0.89)\end{array}$ & $\begin{array}{r}-0.379 \\
(0.9)\end{array}$ & $\begin{array}{r}-0.328 \\
(0.9)\end{array}$ & $\begin{array}{c}-0.321 \\
(0.9)\end{array}$ \\
\hline \multicolumn{6}{|l|}{ Credit line } \\
\hline increase/decrease & $\begin{array}{l}0.677 \\
(0.79)\end{array}$ & $\begin{array}{r}0.677 \\
(0.79)\end{array}$ & $\begin{array}{l}0.655 \\
(0.79)\end{array}$ & $\begin{array}{l}0.607 \\
(0.76)\end{array}$ & $\begin{array}{l}0.604 \\
(0.76)\end{array}$ \\
\hline Credit reporting & $\begin{array}{l}0.119 \\
(0.77)\end{array}$ & $\begin{array}{l}0.119 \\
(0.77)\end{array}$ & $\begin{array}{r}0.119 \\
(0.77)\end{array}$ & $\begin{array}{l}0.139 \\
(0.76)\end{array}$ & $\begin{array}{l}0.138 \\
(0.76)\end{array}$ \\
\hline \multicolumn{6}{|l|}{ Customer } \\
\hline service/customer relations & $\begin{array}{r}-0.73 \\
(0.79)\end{array}$ & $\begin{array}{r}-0.73 \\
(0.79)\end{array}$ & $\begin{array}{r}-0.749 \\
(0.79)\end{array}$ & $\begin{array}{r}-0.754 \\
(0.79)\end{array}$ & $\begin{array}{l}-0.755 \\
(0.79)\end{array}$ \\
\hline Delinquent account & $\begin{array}{l}-0.231 \\
(1.23)\end{array}$ & $\begin{array}{r}-0.231 \\
(1.23)\end{array}$ & $\begin{array}{r}-0.24 \\
(1.22)\end{array}$ & $\begin{array}{r}-0.175 \\
(1.18)\end{array}$ & $\begin{array}{l}-0.178 \\
(1.18)\end{array}$ \\
\hline \multicolumn{6}{|l|}{ Forbearance/workout } \\
\hline plans & $\begin{array}{r}-1.615 \\
(0.99)\end{array}$ & $\begin{array}{r}-1.615 \\
(0.99)\end{array}$ & $\begin{array}{r}-1.608 \\
(0.99)\end{array}$ & $\begin{array}{r}-1.678 \\
(0.97)\end{array}$ & $\begin{array}{l}-1.68 \\
(0.97)\end{array}$ \\
\hline \multicolumn{6}{|l|}{ Identity } \\
\hline theft/fraud/embezzlement & $\begin{array}{r}-0.341 \\
(0.83)\end{array}$ & $\begin{array}{r}-0.341 \\
(0.83)\end{array}$ & $\begin{array}{r}-0.347 \\
(0.83)\end{array}$ & $\begin{array}{r}-0.231 \\
(0.84)\end{array}$ & $\begin{array}{l}-0.23 \\
(0.84)\end{array}$ \\
\hline Late fee & $\begin{array}{r}-0.095 \\
(0.89)\end{array}$ & $\begin{array}{r}-0.095 \\
(0.89)\end{array}$ & $\begin{array}{r}-0.108 \\
(0.89)\end{array}$ & $\begin{array}{r}-0.084 \\
(0.87)\end{array}$ & $\begin{array}{l}-0.088 \\
(0.88)\end{array}$ \\
\hline $\begin{array}{l}\text { Loan modification, } \\
\text { collection, foreclosure }\end{array}$ & $\begin{array}{r}2.454 \\
(1.73)\end{array}$ & $\begin{array}{r}2.454 \\
(1.73)\end{array}$ & $\begin{array}{r}2.252 \\
(1.6)\end{array}$ & $\begin{array}{r}2.406 \\
(1.6)\end{array}$ & $\begin{array}{l}2.393 \\
(1.6)\end{array}$ \\
\hline $\begin{array}{l}\text { Loan services, payments, } \\
\text { escrow account }\end{array}$ & $\begin{array}{l}2.391 \\
(1.78)\end{array}$ & $\begin{array}{r}2.39 \\
(1.78)\end{array}$ & $\begin{array}{r}2.203 \\
(1.67)\end{array}$ & $\begin{array}{l}2.321 \\
(1.67)\end{array}$ & $\begin{array}{l}2.317 \\
(1.67)\end{array}$ \\
\hline Other & $\begin{array}{r}-0.208 \\
(0.85)\end{array}$ & $\begin{array}{l}-0.208 \\
(0.85)\end{array}$ & $\begin{array}{r}-0.209 \\
(0.86)\end{array}$ & $\begin{array}{r}-0.127 \\
(0.83)\end{array}$ & $\begin{array}{l}-0.128 \\
(0.83)\end{array}$ \\
\hline Other fee & $\begin{array}{r}-0.169 \\
(1.02)\end{array}$ & $\begin{array}{l}-0.169 \\
(1.02)\end{array}$ & $\begin{array}{l}-0.178 \\
(1.01)\end{array}$ & $\begin{array}{r}-0.15 \\
(1.01)\end{array}$ & $\begin{array}{l}-0.15 \\
(1.01)\end{array}$ \\
\hline Over limit fee & $\begin{array}{l}0.772 \\
(1.96)\end{array}$ & $\begin{array}{l}0.772 \\
(1.96)\end{array}$ & $\begin{array}{r}0.749 \\
(1.96)\end{array}$ & $\begin{array}{l}0.654 \\
(1.94)\end{array}$ & $\begin{array}{l}0.649 \\
(1.94)\end{array}$ \\
\hline Payoff process & $\begin{array}{r}-0.167 \\
(0.82)\end{array}$ & $\begin{array}{l}-0.167 \\
(0.82)\end{array}$ & $\begin{array}{r}-0.165 \\
(0.82)\end{array}$ & $\begin{array}{r}-0.199 \\
(0.81)\end{array}$ & $\begin{array}{l}-0.203 \\
(0.81)\end{array}$ \\
\hline
\end{tabular}




\begin{tabular}{|c|c|c|c|c|c|}
\hline Privacy & $\begin{array}{r}-0.55 \\
(1.38)\end{array}$ & $\begin{array}{r}-0.55 \\
(1.38)\end{array}$ & $\begin{array}{r}-0.538 \\
(1.38)\end{array}$ & $\begin{array}{r}-0.515 \\
(1.39)\end{array}$ & $\begin{array}{l}-0.521 \\
(1.39)\end{array}$ \\
\hline Rewards & $\begin{array}{l}0.967 \\
(0.86)\end{array}$ & $\begin{array}{l}0.967 \\
(0.86)\end{array}$ & $\begin{array}{l}0.956 \\
(0.86)\end{array}$ & $\begin{array}{l}0.943 \\
(0.85)\end{array}$ & $\begin{array}{l}0.943 \\
(0.85)\end{array}$ \\
\hline Sale of account & $\begin{array}{r}-1.272 \\
(1.22)\end{array}$ & $\begin{array}{r}-1.272 \\
(1.22)\end{array}$ & $\begin{array}{r}-1.325 \\
(1.22)\end{array}$ & $\begin{array}{r}-1.27 \\
(1.27)\end{array}$ & $\begin{array}{l}-1.219 \\
(1.27)\end{array}$ \\
\hline costs & $\begin{array}{r}2.284 \\
(1.7)\end{array}$ & $\begin{array}{r}2.283 \\
(1.7)\end{array}$ & $\begin{array}{r}2.058 \\
(1.6)\end{array}$ & $\begin{array}{r}2.157 \\
(1.6)\end{array}$ & $\begin{array}{l}2.156 \\
(1.6)\end{array}$ \\
\hline Transaction issue & $\begin{array}{l}0.695 \\
(0.71)\end{array}$ & $\begin{array}{l}0.695 \\
(0.71)\end{array}$ & $\begin{array}{l}0.645 \\
(0.71)\end{array}$ & $\begin{array}{r}0.599 \\
(0.7)\end{array}$ & $\begin{array}{c}0.601 \\
(0.7)\end{array}$ \\
\hline \multicolumn{6}{|c|}{$\begin{array}{l}\text { Panel B: Submission } \\
\text { mechanisms and dummies }\end{array}$} \\
\hline Military & & $\begin{array}{l}0.412 \\
(0.38)\end{array}$ & & $\begin{array}{r}0.29 \\
(0.36)\end{array}$ & $\begin{array}{l}0.279 \\
(0.37)\end{array}$ \\
\hline Email & & & $\begin{array}{l}0.573 \\
(0.79)\end{array}$ & $\begin{array}{r}0.557 \\
(0.8)\end{array}$ & $\begin{array}{l}0.576 \\
(0.8)\end{array}$ \\
\hline Phone & & & $\begin{array}{r}-0.477 \\
(0.29)\end{array}$ & $\begin{array}{r}-0.486 \\
(0.3)\end{array}$ & $\begin{array}{c}-0.487 \\
(0.3)\end{array}$ \\
\hline Web & & & $\begin{array}{r}0.04 \\
(0.28)\end{array}$ & $\begin{array}{l}0.069 \\
(0.29)\end{array}$ & $\begin{array}{l}0.064 \\
(0.29)\end{array}$ \\
\hline Postal mail & & & $\begin{array}{r}-0.358 \\
(0.4)\end{array}$ & $\begin{array}{r}-0.437 \\
(0.41)\end{array}$ & $\begin{array}{l}0.434 \\
(0.41)\end{array}$ \\
\hline Referral & & & $\begin{array}{r}-0.011 \\
(0.26)\end{array}$ & $\begin{array}{r}-0.038 \\
(0.26)\end{array}$ & $\begin{array}{l}-0.051 \\
(0.26)\end{array}$ \\
\hline Year dummies & No & No & No & Yes & Yes \\
\hline $\begin{array}{l}\text { Company above- } \\
\text { average dummies }\end{array}$ & No & No & No & No & Yes \\
\hline$R^{2}$ & 0.005 & 0.005 & 0.005 & 0.007 & 0.007 \\
\hline $\mathrm{N}$ & 62300 & 62300 & 62300 & 62300 & 62300 \\
\hline
\end{tabular}

Notes: Source: Consumer Financial Protection Bureau. Robust standard errors clustered at the state level, including military states. OLS regressions include submission mechanism-, issue-, company, and year-related dummy variables. Significance levels: $* * * p<0.01, * * p<0.05, *$ $p<0.1$. 
Table 8: Open Data and Day Complaint was Received

\begin{tabular}{|c|c|c|c|c|c|}
\hline & (1) & (2) & (3) & (4) & (5) \\
\hline Open Data & $\begin{array}{c}1.635^{* * *} \\
(0.11)\end{array}$ & $\begin{array}{r}1.635^{* * *} \\
(0.11)\end{array}$ & $\begin{array}{c}1.621^{* * * *} \\
(0.1)\end{array}$ & $\begin{array}{c}1.684^{* * *} \\
(0.11)\end{array}$ & $\begin{array}{c}1.683^{* * *} \\
(0.11)\end{array}$ \\
\hline Credit card & $\begin{array}{c}-1.112^{* * *} \\
(0.09)\end{array}$ & $\begin{array}{r}-1.112^{* * *} \\
(0.09)\end{array}$ & $\begin{array}{c}1.4 \\
(1.51)\end{array}$ & $\begin{array}{l}1.369 \\
(1.42)\end{array}$ & $\begin{array}{l}1.328 \\
(1.42)\end{array}$ \\
\hline Submitted by email & $\begin{array}{l}0.382 \\
(0.73)\end{array}$ & $\begin{array}{l}0.382 \\
(0.73)\end{array}$ & & $\begin{array}{l}0.447 \\
(0.74)\end{array}$ & $\begin{array}{l}0.471 \\
(0.73)\end{array}$ \\
\hline Submitted by fax & $\begin{array}{c}0 \\
\text { (.) }\end{array}$ & $\begin{array}{c}0 \\
(.)\end{array}$ & & $\begin{array}{c}0 \\
(.)\end{array}$ & $\begin{array}{c}0 \\
(.)\end{array}$ \\
\hline Submitted by phone & $\begin{array}{c}-0.345 \\
(0.3)\end{array}$ & $\begin{array}{r}-0.345 \\
(0.3)\end{array}$ & & $\begin{array}{l}-0.347 \\
(0.3)\end{array}$ & $\begin{array}{c}-0.348 \\
(0.3)\end{array}$ \\
\hline $\begin{array}{l}\text { Submitted by postal } \\
\text { mail }\end{array}$ & $\begin{array}{l}-0.699 \\
(0.78)\end{array}$ & $\begin{array}{r}-0.699 \\
(0.78)\end{array}$ & & $\begin{array}{l}-0.202 \\
(0.35)\end{array}$ & $\begin{array}{c}-0.2 \\
(0.35)\end{array}$ \\
\hline Submitted by referral & $\begin{array}{l}-0.02 \\
(0.28)\end{array}$ & $\begin{array}{r}-0.02 \\
(0.28)\end{array}$ & & $\begin{array}{l}-0.029 \\
(0.27)\end{array}$ & $\begin{array}{l}-0.041 \\
(0.27)\end{array}$ \\
\hline Submitted by web & $\begin{array}{l}0.068 \\
(0.28)\end{array}$ & $\begin{array}{l}0.068 \\
(0.28)\end{array}$ & & $\begin{array}{l}0.096 \\
(0.29)\end{array}$ & $\begin{array}{l}0.093 \\
(0.29)\end{array}$ \\
\hline Military & & $\begin{array}{l}0.725 \\
(0.54)\end{array}$ & $\begin{array}{l}0.677 \\
(0.49)\end{array}$ & $\begin{array}{l}0.545 \\
(0.59)\end{array}$ & $\begin{array}{l}0.535 \\
(0.58)\end{array}$ \\
\hline $\begin{array}{l}\text { Including year } \\
\text { dummies? }\end{array}$ & No & No & No & Yes & Yes \\
\hline $\begin{array}{l}\text { Including } 37 \text { complain } \\
\text { issues? } \\
\text { Including }\end{array}$ & No & Yes & Yes & Yes & Yes \\
\hline $\begin{array}{l}\text { company above- } \\
\text { average complaint } \\
\text { dummies? }\end{array}$ & No & No & No & No & Yes \\
\hline $\mathrm{R}^{2}$ & 0.003 & 0.003 & 0.005 & 0.008 & 0.008 \\
\hline $\mathrm{N}$ & 73525 & 73525 & 73525 & 73525 & 73525 \\
\hline
\end{tabular}

Notes: Source: Consumer Financial Protection Bureau. Robust standard errors clustered at the state level, including military states. OLS regressions include submission mechanism-, issue-, company, and year-related dummy variables. Significance levels: ${ }^{* * *} p<0.01,{ }^{* *} p<0.05,{ }^{*}$ $p<0.1$. 
Table 9: Open Data and Company Responses for the Top 2 and Bottom 2 Counties

\begin{tabular}{|c|c|c|c|c|c|c|}
\hline & (1) & (2) & (3) & (4) & (5) & (6) \\
\hline Open Data & 0.81 & -0.012 & 0.063 & -0.073 & 0.025 & -0.002 \\
\hline$X$ top2 & $(1.56)$ & $(0.01)$ & $(0.08)$ & $(0.06)$ & $(0.05)$ & $(0.01)$ \\
\hline Open Data & -0.25 & 0.038 & -0.018 & -0.057 & 0.048 & -0.002 \\
\hline $\mathrm{X}$ bottom 2 & $(0.95)$ & $(0.02)$ & $(0.05)$ & $(0.04)$ & $(0.04)$ & (0) \\
\hline Open Data & $\begin{array}{c}1.632^{* * *} \\
(0.13)\end{array}$ & $\begin{array}{c}0.005^{* * *} \\
(0.001)\end{array}$ & $\begin{array}{c}0.331^{* * *} \\
(0.006)\end{array}$ & $\begin{array}{c}0.218^{* * *} \\
(0.01)\end{array}$ & $\begin{array}{c}0.088^{* * *} \\
(0.004)\end{array}$ & $\begin{array}{c}-0.004^{* * *} \\
(0.001)\end{array}$ \\
\hline top2 & $\begin{array}{l}0.249 \\
(0.72)\end{array}$ & $\begin{array}{l}-0.002 \\
(0.01)\end{array}$ & $\begin{array}{c}0.04 \\
(0.03)\end{array}$ & $\begin{array}{l}0.014 \\
(0.02)\end{array}$ & $\begin{array}{l}-0.03 \\
(0.02)\end{array}$ & $\begin{array}{l}0.001 \\
(0.01)\end{array}$ \\
\hline bottom2 & $\begin{array}{c}0.209 \\
(0.3)\end{array}$ & $\begin{array}{l}-0.006 \\
(0.005)\end{array}$ & $\begin{array}{c}0.02 \\
(0.02)\end{array}$ & $\begin{array}{l}-0.009 \\
(0.005)\end{array}$ & $\begin{array}{c}-0.01 \\
(0.01)\end{array}$ & $\begin{array}{c}0.002 \\
(0.003)\end{array}$ \\
\hline Credit card & $\begin{array}{c}1.435^{* * *} \\
(0.37)\end{array}$ & $\begin{array}{c}-0.029 * * * \\
(0.01)\end{array}$ & $\begin{array}{c}-0.487^{* * *} \\
(0.02)\end{array}$ & $\begin{array}{c}-0.025^{*} \\
(0.01)\end{array}$ & $\begin{array}{c}-0.069 * * * \\
(0.01)\end{array}$ & $\begin{array}{c}0.005^{*} \\
(0)\end{array}$ \\
\hline Email & $\begin{array}{c}0 \\
(.)\end{array}$ & $\begin{array}{c}0 \\
(.)\end{array}$ & $\begin{array}{c}0 \\
(.)\end{array}$ & $\begin{array}{c}0 \\
(.)\end{array}$ & $\begin{array}{c}0 \\
(.)\end{array}$ & $\begin{array}{c}0 \\
(.)\end{array}$ \\
\hline Fax & $\begin{array}{l}-0.697 \\
(0.73)\end{array}$ & $\begin{array}{l}-0.013 \\
(0.01)\end{array}$ & $\begin{array}{c}0.215^{* * *} \\
(0.04)\end{array}$ & $\begin{array}{l}-0.009 \\
(0.02)\end{array}$ & $\begin{array}{c}0.01 \\
(0.02)\end{array}$ & $\begin{array}{l}-0.011 \\
(0.01)\end{array}$ \\
\hline Phone & $\begin{array}{c}-1.022 \\
(0.7)\end{array}$ & $\begin{array}{l}-0.013 \\
(0.01)\end{array}$ & $\begin{array}{c}0.084^{*} \\
(0.04)\end{array}$ & $\begin{array}{l}-0.006 \\
(0.02)\end{array}$ & $\begin{array}{l}0.043^{*} \\
(0.02)\end{array}$ & $\begin{array}{l}-0.008 \\
(0.01)\end{array}$ \\
\hline Postal mail & $\begin{array}{c}-0.894 \\
(0.7)\end{array}$ & $\begin{array}{l}-0.009 \\
(0.01)\end{array}$ & $\begin{array}{c}0.160^{* * *} \\
(0.04)\end{array}$ & $\begin{array}{l}-0.014 \\
(0.02)\end{array}$ & $\begin{array}{c}0.048^{* *} \\
(0.02)\end{array}$ & $\begin{array}{l}-0.009 \\
(0.01)\end{array}$ \\
\hline Referral & $\begin{array}{l}-0.779 \\
(0.69)\end{array}$ & $\begin{array}{l}-0.006 \\
(0.01)\end{array}$ & $\begin{array}{l}0.077 \\
(0.04)\end{array}$ & $\begin{array}{l}-0.004 \\
(0.02)\end{array}$ & $\begin{array}{c}0.053^{* * *} \\
(0.02)\end{array}$ & $\begin{array}{l}-0.006 \\
(0.01)\end{array}$ \\
\hline Web & $\begin{array}{l}-0.649 \\
(0.69)\end{array}$ & $\begin{array}{l}-0.013 \\
(0.01)\end{array}$ & $\begin{array}{l}0.079^{*} \\
(0.04)\end{array}$ & $\begin{array}{l}-0.001 \\
(0.02)\end{array}$ & $\begin{array}{l}0.038^{*} \\
(0.02)\end{array}$ & $\begin{array}{l}-0.008 \\
(0.01)\end{array}$ \\
\hline $\begin{array}{l}\text { Year } \\
\text { dummies? } \\
\text { Issue }\end{array}$ & Yes & Yes & Yes & Yes & Yes & Yes \\
\hline $\begin{array}{l}\text { dummies? } \\
\text { Company } \\
\text { above- } \\
\text { average }\end{array}$ & Yes & Yes & Yes & Yes & Yes & Yes \\
\hline $\begin{array}{l}\text { complaint } \\
\text { dummies? }\end{array}$ & Yes & Yes & Yes & Yes & Yes & Yes \\
\hline $\mathrm{R}^{2}$ & 0.008 & 0.005 & 0.179 & 0.169 & 0.021 & 0.004 \\
\hline$N$ & 74244 & 74244 & 74244 & 74244 & 74244 & 74244 \\
\hline
\end{tabular}

Notes: Source: Consumer Financial Protection Bureau. Robust standard errors clustered the state level, including military states. OLS regressions include submission mechanism-, issue-, company, and year-related dummy variables. Significance levels: ${ }^{* * *} \mathrm{p}<0.01,{ }^{* *} \mathrm{p}<0.05,{ }^{*}$ $\mathrm{p}<0.1$. 
Table 10: Open Data and Company Responses for the Top 3 and Bottom 3 Counties

\begin{tabular}{|c|c|c|c|c|c|c|}
\hline & (1) & (2) & (3) & (4) & (5) & (6) \\
\hline Open Data & 1.707 & $-0.020^{*}$ & -0.014 & -0.039 & 0.061 & 0.00002 \\
\hline$X$ top3 & $(1.03)$ & $(0.01)$ & $(0.06)$ & $(0.05)$ & $(0.04)$ & $(0.004)$ \\
\hline Open Data & 0.057 & 0.031 & -0.011 & -0.049 & 0.047 & -0.001 \\
\hline$x$ bottom 3 & $(0.88)$ & $(0.02)$ & $(0.05)$ & $(0.04)$ & $(0.04)$ & $(0.002)$ \\
\hline Open Data & $\begin{array}{c}1.622^{* * *} \\
(0.13)\end{array}$ & $\begin{array}{c}0.005^{* * *} \\
(0.001)\end{array}$ & $\begin{array}{c}0.331 * * * \\
(0.01)\end{array}$ & $\begin{array}{c}0.218^{* * *} \\
(0.005)\end{array}$ & $\begin{array}{c}0.087 * * * \\
(0.004)\end{array}$ & $\begin{array}{c}-0.004^{* * *} \\
(0.001)\end{array}$ \\
\hline Top3 & $\begin{array}{l}-0.523 \\
(0.44)\end{array}$ & $\begin{array}{l}0.005 \\
(0.01)\end{array}$ & $\begin{array}{l}0.017 \\
(0.02)\end{array}$ & $\begin{array}{l}0.018 \\
(0.01)\end{array}$ & $\begin{array}{c}-0.030^{* *} \\
(0.01)\end{array}$ & $\begin{array}{c}0.00003 \\
(0.004)\end{array}$ \\
\hline Bottom3 & $\begin{array}{l}0.191 \\
(0.28)\end{array}$ & $\begin{array}{c}-0.004 \\
(0.005)\end{array}$ & $\begin{array}{l}0.019 \\
(0.01)\end{array}$ & $\begin{array}{c}-0.010^{*} \\
(0.004)\end{array}$ & $\begin{array}{l}-0.014 \\
(0.01)\end{array}$ & $\begin{array}{c}0.001 \\
(0.002)\end{array}$ \\
\hline Credit card & $\begin{array}{c}1.438^{* * *} \\
(0.37)\end{array}$ & $\begin{array}{c}-0.029 * * * \\
(0.01)\end{array}$ & $\begin{array}{c}-0.487^{* * *} \\
(0.02)\end{array}$ & $\begin{array}{l}0.025^{*} \\
(0.01)\end{array}$ & $\begin{array}{c}-0.069^{* * *} \\
(0.01)\end{array}$ & $\begin{array}{l}0.005^{*} \\
(0)\end{array}$ \\
\hline Email & $\begin{array}{c}0 \\
(.)\end{array}$ & $\begin{array}{c}0 \\
(.)\end{array}$ & $\begin{array}{c}0 \\
(.)\end{array}$ & $\begin{array}{l}0 \\
(.)\end{array}$ & $\begin{array}{c}0 \\
\text { (.) }\end{array}$ & $\begin{array}{c}0 \\
(.)\end{array}$ \\
\hline Fax & $\begin{array}{l}-0.695 \\
(0.73)\end{array}$ & $\begin{array}{l}-0.013 \\
(0.01)\end{array}$ & $\begin{array}{c}0.215^{* * *} \\
(0.04)\end{array}$ & $\begin{array}{l}-0.009 \\
(0.02)\end{array}$ & $\begin{array}{c}0.01 \\
(0.02)\end{array}$ & $\begin{array}{l}-0.011 \\
(0.01)\end{array}$ \\
\hline Phone & $\begin{array}{c}-1.019 \\
(0.7)\end{array}$ & $\begin{array}{l}-0.013 \\
(0.01)\end{array}$ & $\begin{array}{l}0.084 \\
(0.04)\end{array}$ & $\begin{array}{l}-0.006 \\
(0.02)\end{array}$ & $\begin{array}{c}0.043^{* *} \\
(0.02)\end{array}$ & $\begin{array}{l}-0.008 \\
(0.01)\end{array}$ \\
\hline Postal mail & $\begin{array}{l}-0.89 \\
(0.7)\end{array}$ & $\begin{array}{l}-0.009 \\
(0.01)\end{array}$ & $\begin{array}{c}0.160^{* * *} \\
(0.04)\end{array}$ & $\begin{array}{l}-0.014 \\
(0.02)\end{array}$ & $\begin{array}{c}0.048^{* *} \\
(0.02)\end{array}$ & $\begin{array}{l}-0.009 \\
(0.01)\end{array}$ \\
\hline Referral & $\begin{array}{l}-0.777 \\
(0.69)\end{array}$ & $\begin{array}{l}-0.006 \\
(0.01)\end{array}$ & $\begin{array}{l}0.077 \\
(0.04)\end{array}$ & $\begin{array}{l}-0.004 \\
(0.02)\end{array}$ & $\begin{array}{c}0.053 * * * \\
(0.02)\end{array}$ & $\begin{array}{l}-0.006 \\
(0.01)\end{array}$ \\
\hline Web & $\begin{array}{l}-0.646 \\
(0.69)\end{array}$ & $\begin{array}{l}-0.013 \\
(0.01)\end{array}$ & $\begin{array}{l}0.079^{*} \\
(0.04)\end{array}$ & $\begin{array}{l}-0.001 \\
(0.02)\end{array}$ & $\begin{array}{c}0.038^{* *} \\
(0.02)\end{array}$ & $\begin{array}{l}-0.008 \\
(0.01)\end{array}$ \\
\hline Year dummies? & Yes & Yes & Yes & Yes & Yes & Yes \\
\hline $\begin{array}{l}\text { Issue dummies? } \\
\text { Company } \\
\text { complaint }\end{array}$ & Yes & Yes & Yes & Yes & Yes & Yes \\
\hline dummies? & Yes & Yes & Yes & Yes & Yes & Yes \\
\hline $\mathrm{R}^{2}$ & 0.008 & 0.005 & 0.179 & 0.169 & 0.021 & 0.004 \\
\hline $\mathrm{N}$ & 74244 & 74244 & 74244 & 74244 & 74244 & 74244 \\
\hline
\end{tabular}

Notes: Source: Consumer Financial Protection Bureau. Robust standard errors clustered the state level, including military states. OLS regressions include submission mechanism-, issue-, company, and year-related dummy variables. Significance levels: ${ }^{* * *} p<0.01,{ }^{* *} p<0.05,{ }^{*}$ $\mathrm{p}<0.1$. 
Table 11: The Effect of Being in Charlotte, NC interacted with Open Data

\begin{tabular}{|c|c|c|c|c|c|c|}
\hline & $(1)$ & $(2)$ & (3) & (4) & (5) & (6) \\
\hline Open Data & -1.014 & 0.03 & 0.075 & -0.081 & -0.009 & 0.001 \\
\hline$x$ Charlotte & $(1.38)$ & $(0.03)$ & $(0.07)$ & $(0.05)$ & $(0.05)$ & $(0)$ \\
\hline Open Data & $\begin{array}{c}1.637^{* * *} \\
(0.13)\end{array}$ & $\begin{array}{c}0.005^{* * *} \\
(0)\end{array}$ & $\begin{array}{c}0.331^{* * *} \\
(0.01)\end{array}$ & $\begin{array}{c}0.218^{* * *} \\
(0)\end{array}$ & $\begin{array}{c}0.088^{* * *} \\
(0)\end{array}$ & $\begin{array}{c}-0.004^{* * *} \\
(0)\end{array}$ \\
\hline Charlotte & $\begin{array}{l}0.758 \\
(0.45)\end{array}$ & $\begin{array}{l}-0.006 \\
(0.01)\end{array}$ & $\begin{array}{l}0.011 \\
(0.02)\end{array}$ & $\begin{array}{c}-0.017^{* * *} \\
(0)\end{array}$ & $\begin{array}{l}0.007 \\
(0.02)\end{array}$ & $\begin{array}{c}-0.002 \\
(0)\end{array}$ \\
\hline Credit & $1.430^{* * *}$ & $-0.029 * * *$ & $-0.488 * * *$ & $0.025^{*}$ & $-0.069 * * *$ & $0.005^{*}$ \\
\hline Card & $(0.37)$ & $(0.01)$ & $(0.02)$ & $(0)$ & $(0.01)$ & 0() \\
\hline Email & $\begin{array}{l}0 \\
\text { (.) }\end{array}$ & $\begin{array}{l}0 \\
\text { (.) }\end{array}$ & $\begin{array}{l}0 \\
\text { (.) }\end{array}$ & $\begin{array}{l}0 \\
(.)\end{array}$ & $\begin{array}{l}0 \\
\text { (.) }\end{array}$ & $\begin{array}{l}0 \\
\text { (.) }\end{array}$ \\
\hline Fax & $\begin{array}{l}-0.694 \\
(0.73)\end{array}$ & $\begin{array}{l}-0.013 \\
(0.01)\end{array}$ & $\begin{array}{c}0.215^{* * *} \\
(0.04)\end{array}$ & $\begin{array}{l}-0.009 \\
(0.02)\end{array}$ & $\begin{array}{c}0.01 \\
(0.02)\end{array}$ & $\begin{array}{r}-0.011 \\
(0.01)\end{array}$ \\
\hline Phone & $\begin{array}{l}-1.022 \\
(0.69)\end{array}$ & $\begin{array}{l}-0.013 \\
(0.01)\end{array}$ & $\begin{array}{l}0.085 \\
(0.04)\end{array}$ & $\begin{array}{l}-0.006 \\
(0.02)\end{array}$ & $\begin{array}{c}0.043^{* *} \\
(0.02)\end{array}$ & $\begin{array}{l}-0.008 \\
(0.01)\end{array}$ \\
\hline Postal mail & $\begin{array}{c}-0.894 \\
(0.7)\end{array}$ & $\begin{array}{l}-0.009 \\
(0.01)\end{array}$ & $\begin{array}{c}0.160^{* * *} \\
(0.04)\end{array}$ & $\begin{array}{l}-0.014 \\
(0.02)\end{array}$ & $\begin{array}{c}0.048^{* *} \\
(0.02)\end{array}$ & $\begin{array}{l}-0.009 \\
(0.01)\end{array}$ \\
\hline Referral & $\begin{array}{l}-0.778 \\
(0.69)\end{array}$ & $\begin{array}{l}-0.006 \\
(0.01)\end{array}$ & $\begin{array}{l}0.077 \\
(0.04)\end{array}$ & $\begin{array}{l}-0.004 \\
(0.02)\end{array}$ & $\begin{array}{c}0.052^{* * *} \\
(0.02)\end{array}$ & $\begin{array}{l}-0.006 \\
(0.01)\end{array}$ \\
\hline Web & $\begin{array}{l}-0.65 \\
(0.69)\end{array}$ & $\begin{array}{l}-0.013 \\
(0.01)\end{array}$ & $\begin{array}{l}0.079^{*} \\
(0.04)\end{array}$ & $\begin{array}{l}-0.001 \\
(0.02)\end{array}$ & $\begin{array}{c}0.038^{* *} \\
(0.02)\end{array}$ & $\begin{array}{l}-0.008 \\
(0.01)\end{array}$ \\
\hline $\begin{array}{l}\text { Year dummies? } \\
\text { Issue }\end{array}$ & Yes & Yes & Yes & Yes & Yes & Yes \\
\hline $\begin{array}{l}\text { dummies? } \\
\text { Company } \\
\text { above-average } \\
\text { complaint }\end{array}$ & Yes & Yes & Yes & Yes & Yes & Yes \\
\hline dummies? & Yes & Yes & Yes & Yes & Yes & Yes \\
\hline $\mathrm{R}^{2}$ & 0.008 & 0.005 & 0.179 & 0.169 & 0.021 & 0.004 \\
\hline$N$ & 74244 & 74244 & 74244 & 74244 & 74244 & 74244 \\
\hline
\end{tabular}

Notes: Source: Consumer Financial Protection Bureau. Robust standard errors clustered at the state level, including military states. OLS regressions include submission mechanism-, issue-, company, and year-related dummy variables. Significance levels: ${ }^{* * *} \mathrm{p}<0.01,{ }^{* *} \mathrm{p}<0.05,{ }^{*}$ $\mathrm{p}<0.1$. 
Table 12: The Effect of Being in San Jose, CA interacted with Open Data

\begin{tabular}{|c|c|c|c|c|c|c|}
\hline & $(1)$ & (2) & (3) & (4) & (5) & (6) \\
\hline Open Data & 2.43 & $-0.026^{*}$ & -0.125 & 0.006 & 0.105 & 0.002 \\
\hline X San Jose & $(1.29)$ & $(0.01)$ & $(0.09)$ & $(0.08)$ & $(0.07)$ & $(0)$ \\
\hline Open Data & $\begin{array}{c}1.626^{* * *} \\
(0.13)\end{array}$ & $\begin{array}{c}0.006^{* * *} \\
(0.001)\end{array}$ & $\begin{array}{c}0.331^{* * *} \\
(0.01)\end{array}$ & $\begin{array}{c}0.218^{* * *} \\
(0.005)\end{array}$ & $\begin{array}{c}0.088^{* * *} \\
(0.004)\end{array}$ & $\begin{array}{c}-0.004^{* * *} \\
(0.001)\end{array}$ \\
\hline San Jose & $\begin{array}{c}-1.101^{*} \\
(0.54)\end{array}$ & $\begin{array}{c}0.011 \\
(0.01) \\
-\end{array}$ & $\begin{array}{r}-0.001 \\
(0.03)\end{array}$ & $\begin{array}{l}0.021 \\
(0.01)\end{array}$ & $\begin{array}{r}-0.029 \\
(0.02)\end{array}$ & $\begin{array}{l}-0.001 \\
(0.004)\end{array}$ \\
\hline Credit Card & $\begin{array}{c}1.435^{* * *} \\
(0.37)\end{array}$ & $\begin{array}{c}0.029^{* * *} \\
(0.01)\end{array}$ & $\begin{array}{c}-0.488^{* * *} \\
(0.02)\end{array}$ & $\begin{array}{c}0.025^{*} \\
(0.01)\end{array}$ & $\begin{array}{c}-0.069 * * * \\
(0.01)\end{array}$ & $\begin{array}{l}0.005^{*} \\
(0)\end{array}$ \\
\hline Email & $\begin{array}{c}0 \\
\text { (.) }\end{array}$ & $\begin{array}{c}0 \\
\text { (.) }\end{array}$ & $\begin{array}{c}0 \\
(.)\end{array}$ & $\begin{array}{c}0 \\
\text { (.) }\end{array}$ & $\begin{array}{c}0 \\
\text { (.) }\end{array}$ & $\begin{array}{c}0 \\
(.)\end{array}$ \\
\hline Fax & $\begin{array}{l}-0.692 \\
(0.73)\end{array}$ & $\begin{array}{l}-0.013 \\
(0.01)\end{array}$ & $\begin{array}{c}0.215^{* * *} \\
(0.04)\end{array}$ & $\begin{array}{l}-0.009 \\
(0.02)\end{array}$ & $\begin{array}{c}0.01 \\
(0.02)\end{array}$ & $\begin{array}{l}-0.011 \\
(0.01)\end{array}$ \\
\hline Phone & $\begin{array}{c}-1.018 \\
(0.7)\end{array}$ & $\begin{array}{l}-0.013 \\
(0.01)\end{array}$ & $\begin{array}{c}0.085^{*} \\
(0.04)\end{array}$ & $\begin{array}{l}-0.006 \\
(0.02)\end{array}$ & $\begin{array}{c}0.043^{* *} \\
(0.02)\end{array}$ & $\begin{array}{l}-0.009 \\
(0.01)\end{array}$ \\
\hline Postal mail & $\begin{array}{c}-0.888 \\
(0.7)\end{array}$ & $\begin{array}{l}-0.009 \\
(0.01)\end{array}$ & $\begin{array}{c}0.161^{* * *} \\
(0.04)\end{array}$ & $\begin{array}{l}-0.014 \\
(0.02)\end{array}$ & $\begin{array}{c}0.048^{* *} \\
(0.02)\end{array}$ & $\begin{array}{l}-0.009 \\
(0.01)\end{array}$ \\
\hline Referral & $\begin{array}{l}-0.773 \\
(0.69)\end{array}$ & $\begin{array}{l}-0.006 \\
(0.01)\end{array}$ & $\begin{array}{c}0.077^{*} \\
(0.04)\end{array}$ & $\begin{array}{l}-0.004 \\
(0.02)\end{array}$ & $\begin{array}{c}0.053^{* *} \\
(0.02)\end{array}$ & $\begin{array}{l}-0.006 \\
(0.01)\end{array}$ \\
\hline Web & $\begin{array}{l}-0.643 \\
(0.69)\end{array}$ & $\begin{array}{l}-0.013 \\
(0.01)\end{array}$ & $\begin{array}{c}0.080^{*} \\
(0.04)\end{array}$ & $\begin{array}{l}-0.001 \\
(0.02)\end{array}$ & $\begin{array}{c}0.038^{* *} \\
(0.02)\end{array}$ & $\begin{array}{l}-0.008 \\
(0.01)\end{array}$ \\
\hline $\begin{array}{l}\text { Issue } \\
\text { dummies? }\end{array}$ & Yes & Yes & Yes & Yes & Yes & Yes \\
\hline $\begin{array}{l}\text { Year } \\
\text { dummies? } \\
\text { Company } \\
\text { Above- } \\
\text { average }\end{array}$ & Yes & Yes & Yes & Yes & Yes & Yes \\
\hline dummies? & $\begin{array}{c}\text { Yes } \\
0.008\end{array}$ & $\begin{array}{c}\text { Yes } \\
0.005\end{array}$ & $\begin{array}{c}\text { Yes } \\
0.179\end{array}$ & $\begin{array}{c}\text { Yes } \\
0.169\end{array}$ & $\begin{array}{c}\text { Yes } \\
0.021\end{array}$ & $\begin{array}{c}\text { Yes } \\
0.004\end{array}$ \\
\hline $\mathrm{N}$ & 74244 & 74244 & 74244 & 74244 & 74244 & 74244 \\
\hline
\end{tabular}

Notes: Source: Consumer Financial Protection Bureau. Robust standard errors clustered the state level, including military states. OLS regressions include submission mechanism-, issue-, company, and year-related dummy variables. Significance levels: ${ }^{* * *} \mathrm{p}<0.01,{ }^{* *} \mathrm{p}<0.05,{ }^{*}$ $p<0.1$. 
Table 13: Open Data and Consumer Disputed Response (yes)

(1)

(2)

$\begin{array}{lcc}\text { Open Data } & \begin{array}{c}0.017^{* *} \\ (0.01)\end{array} & \begin{array}{c}0.017^{* *} \\ (0.01)\end{array} \\ \text { Credit Card } & \begin{array}{c}0.101^{* *} \\ (0.03)\end{array} & \begin{array}{c}0.099^{* * *} \\ (0.03)\end{array} \\ \text { Email } & 0 & 0 \\ & (.) & (.) \\ \text { Fax } & -0.007 & -0.008 \\ & (0.06) & (0.06) \\ \text { Phone } & 0.015 & 0.014 \\ & (0.04) & (0.04) \\ \text { Postal mail } & -0.047 & -0.048 \\ & (0.04) & (0.04) \\ \text { Referral } & -0.053 & -0.055 \\ & (0.04) & (0.04) \\ \text { Web } & -0.018 & 0.016 \\ & (0.04) & (0.04) \\ \text { Military } & \text { Yes } & \text { Yes } \\ \text { Issue } & \text { Yes } & \text { Yes } \\ \text { dummies? } & & \\ \text { Year } & \text { Yes } & \text { Yes } \\ \text { dummies? } & & \\ \text { Company } & & \\ \text { Above- } & & \\ \text { average } & & \\ \text { dummies? } & \text { No } & \text { Yes } \\ \mathrm{R}^{2} & 0.018 & 0.018 \\ \mathrm{~N} & 72413 & 72413 \\ & & \\ & & \end{array}$

Notes: Source: Consumer Financial Protection Bureau. Robust standard errors clustered the state level, including military states. OLS regressions include submission mechanism-, issue-, company, and year-related dummy variables. Significance levels: ${ }^{* * *} \mathrm{p}<0.01,{ }^{* *} \mathrm{p}<0.05,{ }^{*}$ $p<0.1$. 


\section{References}

- Agarwal Sumit, Souphala Chomsisengphet, Neale Mahoney and Johannes Stroebel. 2015. "Regulating Consumer Financial Products: Evidence from Credit Cards." Quarterly Journal of Economics, 130(1): 111-164.

- Anzia, Sarah F. and Terry M. Moe. 2016. "Do Politicians Use Policy to Make Politics? The Case of Public-Sector Labor Laws.” American Political Science Review, 110(4), 763-777.

- Ashraf, Nava, Dean Karlan, and Wesley Yin. 2006. "Tying Odysseus to the mast: Evidence from a commitment savings product in the Philippines." Quarterly Journal of Economics, 121(2): 635-672.

- Auer, Sören, Christian Bizer, Georgi Kobilarov, Jens Lehmann, Richard Cyganiak, and Zachary Ives. 2007. Dbpedia: A nucleus for a web of open data. Berlin Heidelberg: Springer.

- Bartels L. M. 2008. Unequal Democracy: The Political Economy of the New Gilded Age. New York: Russell Sage Foundation and Princeton University Press.

- Bashir, Omar S. 2015. "Testing Inferences about American Politics: A Review of the "Oligarchy" Result.” Research \& Politics, 2(4): 1-7.

- Bénabou, Roland. 2013. "Groupthink: Collective Delusions in Organizations and Markets." Review of Economic Studies, 80: 429-462.

- Benartzi, Shlomo and Richard H. Thaler. 2013. "Behavioral Economics and the Retirement Savings Crisis." Science, 339(6124): 1152-1153.

- Bertrand, Marianne, and Adair Morse. 2011. "Information disclosure, cognitive biases, and payday borrowing." Journal of Finance, 66(6): 1865-1893.

- Bloomberg. 2013. "Banks Roused by the CFPB's Database of Complaints."

http://www.bloomberg.com/news/articles/2013-04-04/banks-roused-by-the-cfpbs-databaseof-complaints 
- Browne, Simone. 2015. Dark Matters: On the Surveillance of Blackness. Durham, NC: Duke University Press.

- Bryan, Gharad, Dean Karlan, and Scott Nelson. 2010. "Commitment devices.” Annual Review of Economics 2(1): 671-698.

- Campbell John Y. 2016. "Restoring Rational Choice: The Challenge of Consumer Financial Regulation.” American Economic Review: Papers and Proceedings, 106(5): 1-30.

- Campbell, J. Y., S. Giglio, P. Pathak. 2011. "Forced sales and house prices." American Economic Review, 101(5): 2108-2131

- Campbell, J. Y, H. Jackson, B. C. Madrian, P. Tufano. 2011. Consumer Financial Protection. Journal of Economic Perspectives, 25(1): 91-114.

- Campbell, J. Y., H. Jackson, B. C. Madrian, and P. Tufano. 2010. "The regulation of consumer financial products: an introductory essay with four case studies." Harvard Kennedy School Working Paper.

- Chetty, Raj, Nathaniel Hendren, Patrick Kline, and Emmanuel Saez. 2014. "Where is the Land of Opportunity? The Geography of Intergenerational Mobility in the United States." Quarterly Journal of Economics 129(4): 1553-1623.

- Chetty, Raj, Nathaniel Hendren and Lawrence Katz. 2016. "The Effects of Exposure to Better Neighborhoods on Children: New Evidence from the Moving to Opportunity Experiment." American Economic Review, 106(4): 855-902.

- Consumer Financial Protection Bureau. 2011. CFPB Notice of Final Policy Statement Disclosure of Credit Card Complaint Data.

http://files.consumerfinance.gov/f/201206_cfpb_notice-of-final-policy-statement_disclosureof-credit-card-complaint-data.pdf

- Consumer Financial Protection Bureau. 2016. Field Reference. https://cfpb.github.io/api/ccdb/fields.html 
- Drutman, Lee and Alexander Furnas. 2013. "The bigger the bank, the higher the complaint rate" The Sunlight Foundation Blog.

http://sunlightfoundation.com/blog/2013/04/01/bank-complaints/

- Federal Reserve Bank of New York. 2017. Quarterly Report on Household Debt and Credit. Federal Reserve Bank of New York Report. https://www.newyorkfed.org/medialibrary/interactives/householdcredit/data/pdf/HHDC_2016Q4.pdf

- File, Thom and Camille Ryan. 2014. "Computer and Internet Use in the United States." American Community Survey Reports.

http://www.census.gov/content/dam/Census/library/publications/2014/acs/acs-28.pdf

- Francis, David. 2013. "Critics Say Consumer Bureau is an Overreaching Monster.” The Fiscal Times.

http://www.thefiscaltimes.com/Articles/2013/05/30/Critics-Say-Consumer-Bureau-is-anOverreaching-Monster

- Forbes 2013. "Why Banks are Scrambling to Hear Your Complaints."

http://www.forbes.com/sites/investopedia/2013/10/25/why-banks-are-scrambling-to-hearyour-complaints/\#19ca9647495c

- Gilens, Martin. 2012. Affluence and Influence: Economic Inequality and Political Power in America. New York: Russell Sage Foundation and Princeton University Press.

- Gilens, Martin, and Benjamin I. Page. 2014. "Testing Theories of American Politics: Elites, Interest Groups, and Average Citizens.” Perspectives on Politics, 12(3): 564-581

- Goetz, Martin R., Luc Laeven and Ross Levine. 2013. "Identifying the Valuation Effects and Agency Costs of Corporate Diversification: Evidence from the Geographic Diversification of U.S. Banks." Review of Financial Studies, 26(7): 1787-1823. 
- Hastings, Justine S., Brigitte C. Madrian and William L. Skimmyhorn. 2013. "Financial Literacy, Financial Education, and Economic Outcomes.” Annual Review of Economics, 5(1): $347-373$.

- Huijboom, Noor, and Tijs Van den Broek. 2011. “Open Data: An International Comparison of Strategies." European Journal of ePractice, 12(1): 1-13.

- Janssen, Marijn, Yannis Charalabidis, and Anneke Zuiderwijk. 2012. "Benefits, adoption barriers and myths of open data and open government." Information Systems Management, 29(4): 258-268.

- Johnson, Creola. 2012. "Congress Protected the Troops: Can the New CFPB Protect Civilians from Payday Lending." Washington and Lee Law Review, 69(2): 649-727.

- Kessler R.C., G. J Duncan, L. A. Gennetian, L. F. Katz, J. R. Kling, N. A. Sampson, L. Sanbonmatsu, A. M. Zaslavsky, J. Ludwig. 2014. “Associations of Housing Mobility Interventions for Children in High-Poverty Neighborhoods with Subsequent Mental Disorders during Adolescence.” Journal of the American Medical Association, 311 (9): 937-947.

- Kitch, Edmund W. 1990. “The Framing Hypothesis: Is It Supported by Credit Card Issuer Opposition to a Surcharge on a Cash Price?” Journal of Law, Economics, \& Organization, 6(1): $217-233$.

- Miller, Justin, 2016. "First and Foremost, the Wells Fargo Scandal Is About Workers." The American Prospect.

http://prospect.org/article/first-and-foremost-wells-fargo-scandal-about-workers

- New York Times. 2000. "Legislation to Overhaul Laws on Bankruptcy Dies as President Fails to Sign It"

http://www.nytimes.com/2000/12/20/us/legislation-to-overhaul-laws-on-bankruptcy-diesas-president-fails-to-sign-it.html

• New York Times. 2000. "Does This Bank Watchdog Have a Bite?" 
http://www.nytimes.com/2010/03/28/business/28dugan.html?_r=0

- PBS. 2004. "Secret History of the Credit Card: Interview with Edmund Mierzwinski"

http://www.pbs.org/wgbh/pages/frontline/shows/credit/interviews/mierzwinski.html

- Pyke, Alan. 2014. "Debt Collectors Have Harassed Thousands Of Military Servicemembers Over Nonexistent Debts."

http:/thinkprogress.org/economy/2014/03/11/3392311/debt-collectors-soldiers-cfpb/

- Rabin, Matthew. 2013. “Incorporating Limited Rationality into Economics.” Journal of Economic Literature, 51(2): 528-543.

- Reichman, O. J., Matthew B. Jones, and Mark P. Schildhauer. 2011. "Challenges and Opportunities of Open Data in Ecology.” Science, 331(6018): 703-705.

- Slattery, Paul. 2013. "Square pegs in a round hole: SEC regulation of online peer-to-peer lending and the CFPB alternative.” Yale Journal on Regulation, 30(1): 233-276.

- US News and World Report. 2014. "Wall Street Money Floods Washington."

http://www.usnews.com/opinion/economic-intelligence/2014/08/14/wall-streets-moneyis-flooding-congress

- Wall Street Journal. 2011. "Warning Shots on Financial Protection."

http://www.wsj.com/articles/SB10001424052748703507804576130370862263258

- Warren, Elizabeth. 2008. "Product Safety Regulation as a Model for Financial Services Regulation." Journal of Consumer Affairs, 42(3): 452-460.

- Wilmarth, Jr., Arthur E. 2012. “The Financial Services Industry’s Misguided Quest to Undermine the Consumer Financial Protection Bureau." Review of Banking \& Financial Law, 31: 881-956. 
- Zuiderwijk, A., M. Janssen, S. Choenni, R. Meijer, R. S. Alibaks. 2012. "Socio-Technical Impediments of Open Data." Electronic Journal of eGovernment, 10(2): 156-172. 